\title{
Root density drives aggregate stability of soils of different moraine ages in the Swiss Alps
}

\author{
Konrad Greinwald (1) · Tobias Gebauer • Ludwig Treuter • \\ Victoria Kolodziej • Alessandra Musso • Fabian Maier • \\ Florian Lustenberger $\cdot$ Michael Scherer-Lorenzen
}

Received: 28 October 2020 / Accepted: 29 July 2021 / Published online: 10 September 2021

(C) The Author(s) 2021, corrected publication 2022

\begin{abstract}
Aims The stability of hillslopes is an essential ecosystem service, especially in alpine regions with soils prone to erosion. One key variable controlling hillslope stability is soil aggregate stability. We aimed at identifying dominant controls of vegetation parameters on aggregate stability and analysed their importance for soil aggregate stability during landscape development.

Methods We quantified the aggregate stability coefficient (ASC) and measured plant cover, diversity, root mass and root length, density (RMD, RLD) along
\end{abstract}

Responsible Editor: Zhun Mao.

Supplementary Information The online version contains supplementary material available at https://doi. org/10.1007/s11104-021-05111-8.

K. Greinwald $(\bowtie) \cdot$ T. Gebauer · L. Treuter · V. Kolodziej ·

M. Scherer-Lorenzen

Geobotany, Faculty of Biology, University of Freiburg,

Schänzlestrasse 1, 79104 Freiburg, Germany

e-mail: konrad.greinwald@biologie.uni-freiburg.de

K. Greinwald

Hydrology, Faculty of Environment and Natural

Resources, University of Freiburg, Friedrichstraße 39,

79098 Freiburg, Germany

A. Musso - F. Maier · F. Lustenberger

Department of Geography, University of Zürich,

Winterthurerstrasse 190, 8057 Zürich, Switzerland two chronosequences with contrasting bedrocks (siliceous, calcareous) in the Swiss Alps.

Results We found that ASC developed slower along the calcareous chronosequence. Furthermore, we observed a significant positive effect of vegetation cover and diversity on ASC that was mediated via root density. These relationships developed in a timedepended manner: At young terrain ages, vegetation parameters had a strong effect on aggregate stability compared to older stages. Moreover, RLD was the most powerful predictor of ASC on young terrain, whereas on older moraines RMD became more important.

Conclusions We highlight that root density plays a major role in governing ASC for soils differing in moraine ages. The changingimportances of RLD and RMD for ASC development suggest different mechanistic linkages between vegetation and hillsopestability during landscape development.

Keywords Chronosequence $\cdot$ HILLSCAPE $\cdot$ Root density $\cdot$ Shannon index $\cdot$ Soil aggregate stability Vegetation cover

\section{Introduction}

The stability of hillslopes is an essential ecosystem service, especially in populated alpine regions, like the European Alps, with high numbers of tourists (Meusburger und Alewell 2014). In mountainous 
areas, soil formation and development are slow and soil degradation is common [Food and Agriculture Organization of the United Nations (FAO) 2015]. Mountainous landscapes consist largely of steep hillslopes that are prone to erosion, especially above the timberline (Pohl et al. 2009). This high risk of soil erosion is further enhanced by climate change, which is increasing the frequency and intensity of rainfall events in the alpine region (Anache et al. 2018; Nearing et al. 2004) and accelerating glacial retreat, leaving fresh and unconsolidated glacial debris behind (Gobiet et al. 2014). Together with anthropogenic pressure induced by tourism and land-use changes, this leads to an increased risk of natural hazards provoked by soil erosion such as landslides and debris flows (Gobiet et al. 2014; Hudek et al. 2017b). Hence, understanding the development of hillslope stability and identifying its drivers in alpine habitats is key to avoiding further soil degradation and connected risks to human safety in these areas (Hudek et al. 2017b).

Vegetation structures are known to improve hillslope stability and are frequently used in ecological restoration programs (e.g. Bardgett et al. 2014; Liu et al. 2018; Stokes et al. 2009, 2014; Vannoppen et al. 2015). The aboveground compartments of vegetation enhance hillslope stability by reducing the kinetic energy of rainfall and surface runoff through canopy structure and leaf traits, surface runoff through an increased surface roughness, soil water content via transpiration, and sediment transport since vegetation functions as a sediment trap (Geißler et al. 2012; Goebes et al. 2015; Kervroëdan et al. 2019, 2021; Poesen 2018; Vannoppen et al. 2015). Aboveground vegetation characteristics, such as cover and diversity, are known to play a key role for hillslope stability. That is because a densely vegetated plant community with different growth forms and functional traits will be more effective for maintaining hillslope stability than a vegetation cover with few species (Körner und Spehn 2002). The belowground root system of plants controls hillslope stability by increasing the infiltration capacity via root channels, modifying soil texture, organic content as well as chemical composition, and affecting soil shear strength (Amezketa 1999; Burylo et al. 2012; Stokes et al. 2014; Vannoppen et al. 2015). In the context of hillslope stability, belowground plant characteristics have been studied less than the aboveground compartments and are referred to as the "hidden half"
(Bardgett et al. 2014; Eshel und Beeckman 2013). In most cases, high aboveground vegetation cover is positively correlated with root biomass (Martin et al. 2010; Pohl et al. 2009). However, since roots have a more direct impact on many soil stabilizing processes than vegetation cover, it is of relevance to quantify root characteristics. As they are relatively easy to assess, Root Mass Density (RMD = root dry mass per soil volume) and Root Length Density (RLD = root length per soil volume) are normally used in studies dealing with hillslope stability (Pohl et al. 2012; Erktan et al. 2015; Hudek et al. 2017b). However, in alpine habitats, there are only few studies dealing with roots, and even less is known about their role in maintaining ecosystem services above the timberline (Bast et al. 2016; Hudek et al. 2017a, b; Pohl et al. 2009, 2011).

One key variable reflecting hillslope stability is soil aggregate stability. Soil aggregates are groups of soil particles that cohere due to chemical and physical forces (Amezketa 1999). An improved soil aggregate stability will increase soil permeability, lead to an increased infiltration rate, and reduce surface runoff (Vannoppen et al. 2015). Stable aggregates withstand slaking when they are wetted rapidly as they can tolerate the pressure due to swelling (Tisdall and Oades 1982). Consequently, aggregate stability is measured best by testing their water stability, which simulates the natural forces during precipitation. The classical method to determine soil aggregate stability is to measure the aggregate size distribution with a wetsieving approach and then to relate the specific weight of large, stable aggregates to the same weight of small aggregates (Tisdall and Oades 1982). Alternatively, for alpine habitats, a new method [Aggregate Stability Coefficient-(ASC)] has been developed for soils with high stone contents and reducing work effort to a minimum (Bast et al. 2015).

Soil aggregate stability is connected to various biotic (soil organic matter, plant roots, soil fauna, and microorganisms), abiotic (clay minerals, sesquioxides, exchangeable cations), and environmental parameters (soil temperature, moisture and lithology) (Amezketa 1999; Márquez et al. 2004, Pérès et al. 2013). For example, plant litter increases the activity of soil microbes (Blume et al. 2010), which release enzymes that mineralise high molecular weight compounds and polysaccharides (Amezketa 1999). Both factors contribute to soil aggregation. Furthermore, to 


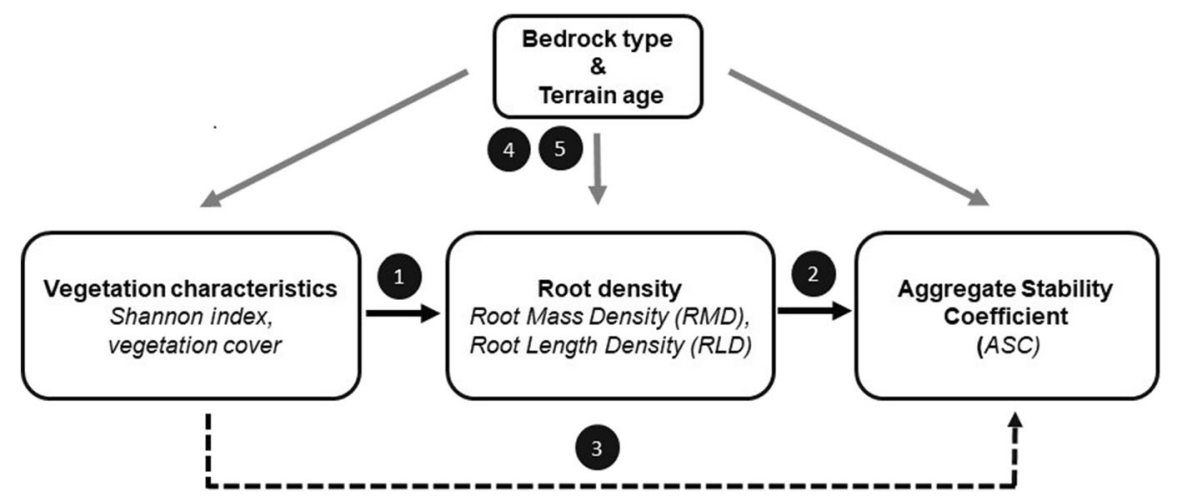

Fig. 1 Illustration of the study hypotheses assessing the vegetation controls of aggregate stability in proglacial areas. (1) Root density (RMD, RLD) is affected by Shannon index and vegetation cover. (2) ASC is a function of root density (RMD, RLD). (3) ASC is a function of Shannon index

support microorganisms at the rhizosphere, increase nutrient availability, and reduce element toxicity, roots release exsudates, which positively affect soil aggregate stability (Bardgett et al. 2014). This is because exudates consist of polysaccharides and proteins, which bond mineral particles together. The flux of primary metabolites through root exsudation is mostly located at the root tip (Canarini et al. 2019) and thus, the amount of fine roots present is of special significance for soil aggregate stability. Another actor at the rhizosphere level secreting exsudates and thereby influencing soil aggregate stability is the hyphal network created by mycorrhizal fungi. As plant species differ in the amounts as well as in the composition of their exsudates and because the occurrence of mycorrhizal fungi is highly plant species-dependent, species composition of plant communities may have a strong impact on soil aggregate stability (Bardgett et al. 2014). One prominent abiotic factor controlling the formation of soil aggregates is lithology (Duan et al. 2021) as it is affecting soil mineralogy and texture as crucial factors for soil aggregation (Bronick and Lal 2005). In soils developed on calcareous bedrock, high clay and calcium concentrations drive the stabilisation of organic matter and the formation of aggregates. In more sandy or acidic soils, the absence of alkaline cations and the coarse soil texture impede the formation of coarse aggregates (Bronick and Lal 2005; Yang et al. 2020).

The most relevant previous studies dealing with the impact of vegetation dynamics on hillslope and vegetation cover. The hypotheses were tested along two chronosequences with contrasting bedrocks (siliceous versus calcareous) and the relationships 1-3 were expected (4) to change in interaction with terrain age and (5) with respect to bedrock type

functioning above the timberline have mainly dealt with narrow environmental gradients (Bast et al. 2014, 2016; Martin et al. 2010; Pohl et al. 2009, 2012). Therefore, little is known about the long-term development of hillslope stability during landscape evolution. We, especially, lack a holistic understanding of its influencing factors, which applies to the underlying interactions, mechanisms, and their relation to the resulting pattern, also in terms of scale linkages. The expanding terrain of glacier forelands is a field laboratory for studying the development of such features as a response to vegetation dynamics. In these habitats, former glacier positions can be identified by moraines representing distinct ages of substrate exposure (e.g. Egli et al. 2001; Musso et al. 2019, 2020). This space for time substitution, called chronosequence approach, enables scientists to test hypotheses related to terrain age and ecologists have frequently used it to study plant succession or soil development. In this study, we used two proglacial chronosequences with contrasting bedrocks (siliceous versus calcareous) to study the development of soil aggregate stability for soils differing in moraine ages and to reveal its interactions with above- and belowground vegetation parameters. Chiefly, we tested the following hypotheses (Fig. 1): We expect that (1) vegetation cover and diversity are positively correlated to RMD and RLD because of density and complementarity effects, respectively (e.g. Ravenek et al. 2014). In addition, we assume that (2) soil aggregate stability correlates positively to RMD and RLD. 
Consequently, if hypothesis 1 and 2 are true, (3) vegetation cover and diversity should be positively correlated with soil aggregate stability. Because Pohl et al. (2012) found that the impact of vegetation on aggregate stability was strongest on slopes with high disturbance, we assume that (4) the relationships described in hypothesis 1-3 vary along the chronosequences, covering a gradient of young moraines with high disturbance regime to old moraines with lower disturbance levels. Specifically, we expect that vegetation parameters play a more important role in governing soil aggregate stability on young than on old moraines. Finally, bedrock is one of the key factors determining rates and speed of vegetation dynamics (Vítovcová et al. 2021), whereby succession is thought to be decelerated in calcareous glacier forelands (Lüdi 1958; Oechslin 1935). Because the vegetation is critical for determining aggregate stability, we assume (5) a slower development of the latter variable at the calcareous glacier foreland.

\section{Material and methods}

Study sites

The study was conducted in two proglacial areas of Central Switzerland (Fig. 2; Table 1). The first site is located west of the Susten Pass, in the foreland of the Stein Glacier, Canton Berne $\left(47^{\circ} 43^{\prime} \mathrm{N}, 8^{\circ} 25^{\prime} \mathrm{E}\right)$. The local bedrock at the Stein Glacier foreland is covered by glacial till on pre-Mesozoic silicate parent material, comprised of metamorphosed metagranitoids, gneisses, and amphibolites (Musso et al. 2019; Schimmelpfennig et al. 2014). The second site is situated $33 \mathrm{~km}$ northeast of Susten Pass, close to the Klausen Pass, in the glacier foreland of the Griess Glacier, Canton Uri $\left(46^{\circ} 50^{\prime} \mathrm{N}, 8^{\circ} 49^{\prime} \mathrm{E}\right)$. Here, the geological substrates are characterized by calcareous material (Globigerinen limestone), schists (Pectinien schist), marl (Globigerinen marl), and some quartzites (Musso et al. 2019; Oechslin 1935). The soils of both chronosequences developed from glacial till; an overview of the soil conditions at the study sites is given in Musso et al. (2019).

The two sites are located above the timberline at an elevation between 1800 and $2300 \mathrm{~m}$ above sea level.
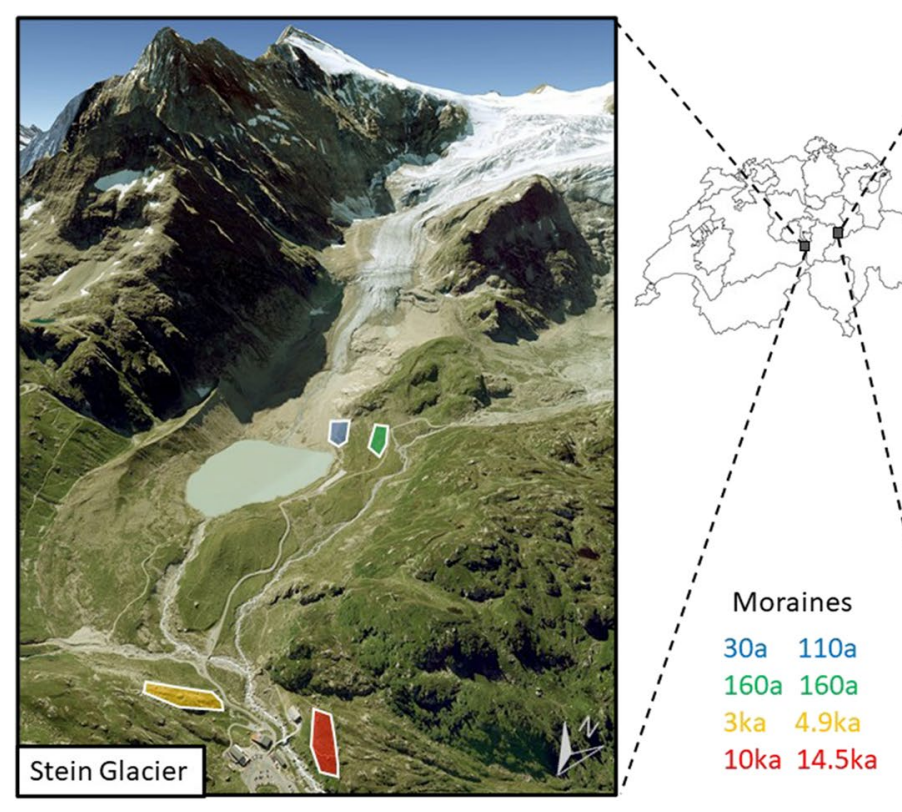

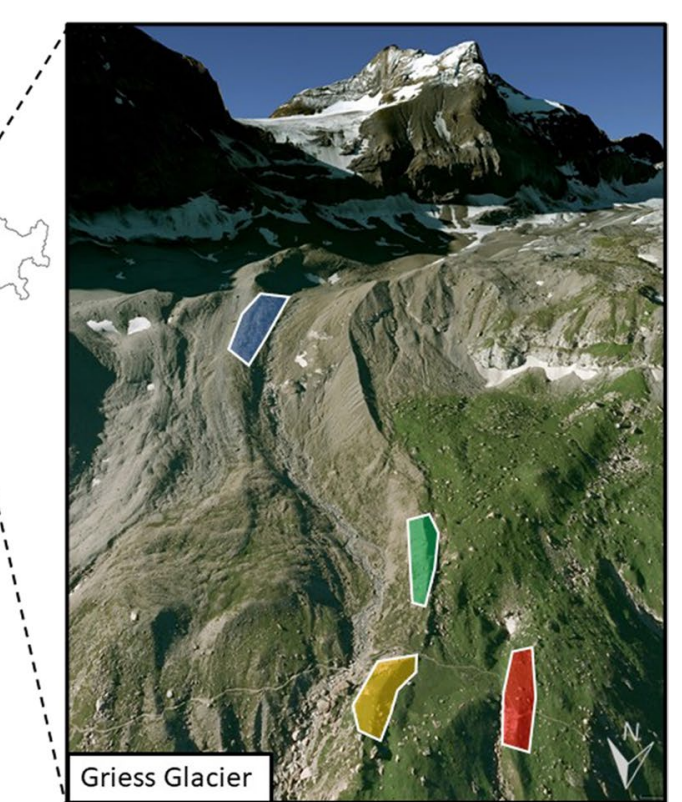

Fig. 2 Location of the study areas in the Swiss Alps: proglacial area of the Stein Glacier (Susten Pass, $47^{\circ} 43^{\prime} \mathrm{N}, 8^{\circ} 25^{\prime} \mathrm{E}$ ) and proglacial area of the Griess Glacier (Klausen Pass, $\left.46^{\circ} 50^{\prime} \mathrm{N}, 8^{\circ} 49^{\prime} \mathrm{E}\right)$. The coloured areas represent the studied moraines forming two chronosequences. Images were taken from DigitalGlobe/Google EarthTMmapping service 
Table 1 Study site characteristics with terrain ages of the moraines (years), elevation (m a.s.l.), slope exposition, slope (\%), bedrock and vegetation type of Stein Glacier and Griess Glacier forelands

\begin{tabular}{|c|c|c|c|c|c|c|}
\hline Glacier foreland & $\begin{array}{l}\text { Moraine } \\
\text { terrain ages }\end{array}$ & $\begin{array}{l}\text { Elevation } \\
\text { [m a.s.l.] }\end{array}$ & Slope exposition & Slope $\left[{ }^{\circ}\right]$ & Bedrock & Vegetation type \\
\hline Stein Glacier & $30 \mathrm{a}$ & 1950 & ENE & 40 & Gneiss & Pioneer vegetation \\
\hline Stein Glacier & $160 \mathrm{a}$ & 1990 & ENE & 31 & Gneiss & Initial grassland and Salix shrubberies \\
\hline Stein Glacier & $3 \mathrm{ka}$ & 1890 & SW & 25 & Gneiss & Carex sempervirens grassland \\
\hline Stein Glacier & $10 \mathrm{ka}$ & 1880 & $\mathrm{~N}$ & 22 & Gneiss & $\begin{array}{l}\text { Rhododendron ferrugineum shrubber- } \\
\text { ies and Nardus grassland }\end{array}$ \\
\hline Griess Glacier & $110 \mathrm{a}$ & 2200 & WNW & 27 & Limestone & Pioneer vegetation \\
\hline Griess Glacier & $160 \mathrm{a}$ & 2030 & NE & 31 & Limestone & Scree vegetation \\
\hline Griess Glacier & $4.9 \mathrm{ka}$ & 2010 & $\mathrm{~N}$ & 37 & Limestone & Carex ferruginea grassland \\
\hline Griess Glacier & $13.5 \mathrm{ka}$ & 2000 & NW & 44 & Limestone & $\begin{array}{l}\text { Rhododendron hirsutum shrubberies } \\
\text { and Carex ferruginea grassland }\end{array}$ \\
\hline
\end{tabular}

According to the closest weather station, at the Grimsel Hospiz (1980 m a.s.l.; $18 \mathrm{~km}$ away from Stein Glacier, and $49 \mathrm{~km}$ from Griess Glacier), the annual air temperature is $1.9{ }^{\circ} \mathrm{C}$, the mean annual precipitation is $1856 \mathrm{~mm}$ year $^{-1}$ and snowfall events are common even during summer (Meteo Swiss 2016). At both sites, we established one chronosequence consisting of four moraines each. At the Stein Glacier site, the terrain ages of the moraines were $30 \mathrm{a}(\mathrm{a}=$ years), 160 a (Little Ice Age), $3 \mathrm{ka}(\mathrm{ka}=1000 \mathrm{~s}$ of years), and $10 \mathrm{ka}$. At Griess Glacier, the ages were 110 a, 160 a (Little Ice Age), $4.9 \mathrm{ka}$, and $13.5 \mathrm{ka}$ (for details of terrain age determination see Musso et al. 2019).

The plant species composition differed strongly between the study sites as well as across the moraines. At the Stein Glacier chronosequence, the vegetation was clustered into four distinct successional stages. At the Griess Glacier site, the two younger and the two older moraines had a similar species composition (Fig. S1a). In terms of plant growth forms, vegetation was mainly dominated by forbs and grasses (Fig. S1b). Typical colonizers of the youngest two moraines on both study areas were creeping dwarf shrubs, e.g. Dryas octopetala, Salix retusa, and pioneer species, e.g. Saxifraga aizoides, Poa alpina. The vegetation of the old moraines was characterized by alpine grassland species, e.g. Nardus stricta, Trifolium pratensis ssp. nivale (Stein Glacier) and Carex ferruginea, Sesleria albicans (Griess Glacier; Table S1).
Sampling design

On all moraines, three plots $(4 \mathrm{~m} \times 6 \mathrm{~m}$ each $)$ were installed, thus establishing a total number of 24 plots. Detailed information on the single plots is provided in Table S1. Plot selection was done based on a structural vegetation complexity measure. Briefly, structural vegetation complexity was defined as an index based on vegetation cover and functional diversity data (Maier et al. 2020). Functional diversity was calculated based on the following eight traits characterizing species along the main axes of plant performance (Garnier et al. 2016): specific leaf area, nitrogen content, leaf dry matter content, Raunkiaeŕs life form, seed mass, clonal growth organ, root type, and stem growth form. For the plot selection, we conducted a vegetation mapping differentiating between vegetation units classified according to the characteristic, recurrent combination of species. In each unit, we recorded all vascular plant species with proportion cover and calculated the vegetation complexity index. On every moraine, the three plots were placed within the surface units with the lowest, intermediate, and highest vegetation complexity (Maier et al. 2020).

In July 2018 (Stein Glacier) and July 2019 (Griess Glacier), a total of 144 soil cores (six per plot) were extracted. Since the study was performed in the scope of the larger HILLSCAPE project including rainfall simulations (see Lustenberger 2019), the plots needed to be undisturbed, and hence sampling took place outside of the plots but as close to them as possible ("off-plot locations", Fig. 3). To ensure that the data gathered was representative for the original 


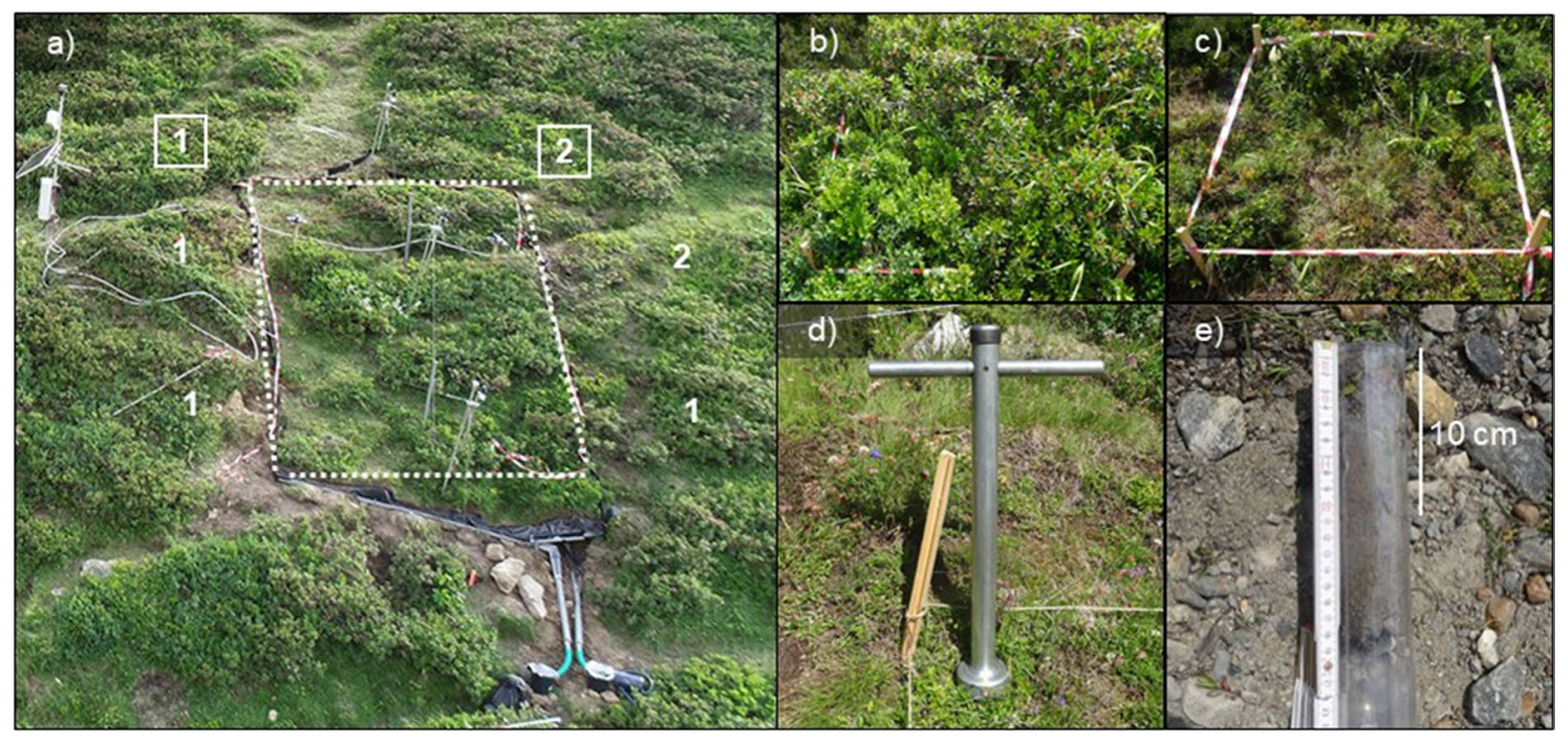

Fig. 3 Sampling design. a One example plot $(4 \mathrm{~m} \times 6 \mathrm{~m}$, indicated by the white dashed line) at the $10 \mathrm{ka}$ moraine. Six soil cores of the two dominating vegetation types were sampled in the vicinity of the plot, in this case four in vegetation type one (indicated by the white number one) and two in vegetation type two (indicated by the white number two). To each of the two vegetation types one sub-plot, where the vegetation surveys were conducted, was assigned $(1 \times 1 \mathrm{~m}$, indicated by the white

HILLSCAPE plots, we visually selected off-plot locations that represented the two dominant vegetation strata of each plot, characterized by growth forms and species identity of its dominant plants. The number of soil cores taken per stratum was determined based on the percentage proportion of the plot area covered by the same stratum. For instance, assuming that a hypothetical plot would have two-thirds of the cover dominated by shrubs (such as Rhododendron ferrugineum and Vaccinium myrtillus), and one third dominated by grassland species (e.g. Nardus stricta and Calamagrostis villosa), four soil cores would be taken in the stratum dominated by shrubs and two soil cores in the stratum dominated by the grassland species in the corresponding off-plot locations. The cores were taken at six randomly selected sampling points that fitted the predefined vegetation strata.

\section{Aboveground characteristics}

Vegetation surveys $(1 \mathrm{~m} \times 1 \mathrm{~m}$ each) were conducted at two of the sampling points of each off-plot location squares). b Sub-plot 1, dominated by the shrubs Rhododendron ferrugineum and Vaccinium myrtillus. c Sub-plot 2, dominated by the graminoids Nardus stricta and Calamagrostis villosa. d Humax probe used for sampling of the soil cores. e Plastic tube of the Humax probe containing a soil core. The topmost $10 \mathrm{~cm}$ were used for the analysis of soil aggregate stability and root density

(each one per vegetation stratum; in total 48 vegetation surveys). The vegetation surveys were conducted within 1 week in mid-July 2018 (Stein Glacier) and 2019 (Griess Glacier), recording the percentage of plant coverage by visual estimation. The species nomenclature followed the latest edition of Flora Helvetica (Lauber et al. 2018). We calculated the Shannon diversity index $(H)$ as a basic diversity parameter (Pielou 1966). The vegetation cover was determined by summing up all single species coverages in each vegetation survey.

\section{Soil cores}

The soil samples were taken within three consecutive days without rainfall in July 2018 (Stein Glacier) and 2019 (Griess Glacier) (Fig. 3). The soil cores were extracted carefully, ensuring that at least the uppermost $10 \mathrm{~cm}$ of the soil below the humus layer (O horizon) was captured. To extract the soil cores a HUMAX probe and a sledgehammer were used (for a detailed description see Bast et al. 2015). When hammering the probe into the ground the soil core was 
pushed directly into a plastic cylinder $(25 \mathrm{~cm} \times 5 \mathrm{~cm})$, thereby minimizing disturbance of the sample. Due to large quantities of stones at several sites sampling was limited to $10 \mathrm{~cm}$ depth. During the coring process, the samples were carefully placed into a box with the topsoil part up and kept in the shade. Afterwards, the samples were stored in a refrigerator at approximately $4{ }^{\circ} \mathrm{C}$. 1 week later they were reloaded into a padded box and transported by car to the laboratory. There they were kept at $4{ }^{\circ} \mathrm{C}$ until soil aggregate stability measurements were completed.

\section{Soil aggregate stability}

To quantify soil aggregate stability we calculated the ASC as proposed by Bast et al. (2015). The method has been previously shown to be successfully applied in alpine environments and was designed for coarsegrained soil with gravel (>2 mm) content above 50\% (Bast et al. 2015, 2016). For measuring ASC, the soil samples (soil cores) were trimmed to a length of $10 \mathrm{~cm}$, excluding the litter layer above the topsoil. Subsequently, the samples were placed on a sieve with a mesh width of $20 \mathrm{~mm}$ standing in a drainable bucket. The bucket was filled with tap water until the sample was covered. After $5 \mathrm{~min}$, a ball valve at the bottom of the bucket was opened to release the water. The soil material trapped within the sieve with a mesh size of $20 \mathrm{~mm}$ as well as the material that passed through the sieve was flushed into two separate bowls. The two fractions were cleaned from roots and other plant material. Stones larger than $2 \mathrm{~mm}$ were removed from both fractions to determine soil volume. The different fractions were dried at $105^{\circ} \mathrm{C}$ for at least $24 \mathrm{~h}$ and then weighed separately. The different fractions were used to calculate the ASC, which is defined as: $A S C=\frac{m_{20 m m}-m_{\text {stones }}}{m_{\text {total }}-m_{\text {stones }}}$, \# where $m_{20 m m}[\mathrm{~g}]$ represents the fraction of soil remaining on the $20 \mathrm{~mm}$ mesh sized sieve, $m_{\text {stones }}$ [g] equals stones larger than $20 \mathrm{~mm}$, and $m_{\text {total }}[\mathrm{g}]$ means the entire soil sample before water treatment (Bast et al. 2015). The ASC ranges from zero to one, zero suggesting a completely disaggregated sample and one implying a stable, fully aggregated sample.
Root mass and root length density

The roots were sorted during the measurement of soil aggregate stability and then stored in a freezer at $-15^{\circ} \mathrm{C}$ until further processing. The roots were then cleaned thoroughly from any remaining soil and prepared for scanning. For this purpose, according to their diameter roots were separated into fine $(<1 \mathrm{~mm})$, and coarse roots $(>1 \mathrm{~mm})$. The roots were put into water-filled petri dishes and scanned with a flatbed scanner. The scanned petri dishes were put into a compartment drier at $60{ }^{\circ} \mathrm{C}$. After the samples were completely dried the weight of the roots was determined.

To reduce the workload, fine roots were subsampled when more than five scans would have been necessary to scan all fine roots of one soil sample. For subsampling, over the mesh grid of a sieve (diameter $20 \mathrm{~cm}$; mesh width $1 \mathrm{~mm}$ ), the roots were uniformly distributed on a paper towel with a defined size. With a round hollow puncher, five randomly selected pieces of the towel were punched out covering $1 \%$ of the area of the sieve mesh grid. The roots attached to the five punched-out pieces were washed into petri dishes and processed analogously to the other roots. The roots still attached to the rest of the paper towel were put into a compartment drier and weighed after the drying process. In this way the root length of the entire sample could be estimated using the dry weight and root length of the scanned subsample as well as the dry weight of the remaining sample.

The root length was measured using WinRHIZO (Régent Instruments Inc 2013). Images were analyzed at $800 \mathrm{dpi}$. RMD was determined by dividing the dry weight of the sample by the soil volume of the corresponding sample. RLD was obtained by dividing the root length by the soil volume. Importantly, we used all root fractions (fine and coarse roots) to calculate RMD and RLD. Because coarse roots considerably affect root biomass, RMD was interpreted as a measure reflecting the accumulation of soil organic matter and related decomposition processes. RLD is instead predominantly driven by fine root and therefore RLD is more related to direct interactions at the root-soil interface, such as the secretion of exudates. To determine the soil volume of each sample, the volume of gravel $(>2 \mathrm{~mm})$ was subtracted from the volume of the corresponding soil cylinder. The volume of stones was determined using the water displacement method. 
Statistical analyses

For testing the study hypotheses, we omputed Linear Mixed-Effect Models (LMERs) (Bates et al. 2007). We used "plot", nested within "moraine" as random effects to account for the spatial nestedness of our data. To detect if the effects on the response varied depending on the terrain age, the interaction between terrain age and a relevant explanatory variable was inspected. Terrain age was implemented as a continuous predictor and was transformed with the decadic logarithm due to the large scaling difference between the younger and older moraines. The study site (Stein Glacier, Griess Glacier) was used as a covariable in the models. To improve model quality, all continuous predictor variables (terrain age, RMD, RLD, Shannon index, vegetation cover) were scaled. The models were built according to the three study hypotheses. As vegetation characteristics (Shannon index, cover) and root density (RMD, RLD) were correlated significantly $(\rho>0.6, p<0.05)$ we set up a single model of every parameter. Further details on the single models are listed in Table 2. All models were checked for outliers and assessed in terms of homogeneous residual distribution and approximate normality (Fig. S2). We calculated post-hoc multiple comparisons of group-specific means to get p-values for the linear mixed effect models (Kuznetsova et al. 2017). Collinearity was tested with variance inflation factors (Zuur et al. 2010). Marginal R-squared values, which are interpreted as the variance explained by the fixed effects, were calculated after the method of Nakagawa and Schielzeth (2013). To visualize the models, effect plots were generated (Fox and Weisberg 2018). The plots show the predictions of model interaction terms by displaying the effects of the root and vegetation predictors at distinct terrain age steps. For this purpose, we chose four different terrain ages (70 a, 160 a, $4 \mathrm{ka}, 12 \mathrm{ka}$ ) that represented mean terrain ages for each pair of moraines of the two study sites (e.g. mean of the two youngest moraines, Stein Glacier (30 a) and Griess Glacier (110 a), which is 70 a).

In addition to the LMERs, we used Principal Component Analysis (PCA) and Structural Equation Modelling (SEM) to investigate how root densities, Shannon index and vegetation cover directly and indirectly affected ASC. SEM is used to test direct and indirect relationships between variables in a multivariate approach. Our study design served as the hypothetical base for the initial SEMs. The PCA and SEM analyses were conducted based on the results of the LMERs, which showed a clear separation for young and for old moraines concerning the relationships between vegetation parameters and ASC. Therefore, we subsetted the whole dataset into two groups: the first group included the two young moraines of each glacier foreland (data of moraines $\leq 160 \mathrm{a}$ : Stein Glacier: 30a, 160a; Griess Glacier: 110a, 160a) and the second group included the two old moraines of each glacier foreland (data of moraines $\geq 3 \mathrm{ka}$ : Stein Glacier: $3 \mathrm{ka}, 10 \mathrm{ka}$; Griess Glacier: $4.9 \mathrm{ka}, 13.5 \mathrm{ka}$ ). In order to account for the terrain-age dependent effects observed from the LMERs, we then ran the PCAs and SEMs separately on each group. The initial two SEM models
Table 2 Structure of the Linear Mixed-Effect Models (LMERs) testing the study hypotheses

$R L D$ Root Length Density, $R M D$ Root Mass Density, ASC Aggregate Stability Coefficient. Random variables: we used "plot" nested in "moraine" as random factors to account for the arising pseudoreplication

\begin{tabular}{|c|c|c|c|}
\hline LMERs & Response & Fixed variables & Random variables \\
\hline \multicolumn{4}{|c|}{ hypotheses $(1,4,5)$ root density $\sim$ vegetation characteristics (Shannon index, cover) } \\
\hline model 1 & RLD & glacier foreland + terrain age*Shannon index & moraine/plot \\
\hline model 2 & RLD & glacier foreland + terrain age ${ }^{*}$ cover & moraine/plot \\
\hline model 3 & RMD & glacier foreland + terrain age $*$ Shannon index & moraine/plot \\
\hline model 4 & RMD & glacier foreland + terrain age $*$ cover & moraine/plot \\
\hline \multicolumn{4}{|c|}{ hypotheses $(2,4,5)$ ASC $\sim$ root density } \\
\hline model 5 & ASC & glacier foreland + terrain age $*$ RLD & moraine/plot \\
\hline model 6 & ASC & glacier foreland + terrain age $*$ RMD & moraine/plot \\
\hline \multicolumn{4}{|c|}{ hypotheses $(3,4,5)$ ASC $\sim$ vegetation characteristics (Shannon index, cover) } \\
\hline model 7 & ASC & glacier foreland + terrain age $*$ Shannon index & moraine/plot \\
\hline model 8 & ASC & glacier foreland + terrain age $*$ cover & moraine/plot \\
\hline
\end{tabular}


were built based on the significant relationships found in the LMERs (f1: ASC $\sim$ RLD + RMD, f2: $\mathrm{RLD} \sim$ Shannon Index, f3: RMD Cover). The models were then simplified until an adequate fit was achieved. The adequacy of the models was determined via $\chi^{2}$-tests, AIC and RMSEA. Adequate model fits are indicated by a non-significant $\chi^{2}$ tests $(\mathrm{p}>0.05)$, low AIC and low RMSEA $(<0.05)$ (Grace 2006). All statistical analyses were performed with $\mathrm{R}$ version 3.5.1 (R Core Team 2018).

\section{Results}

Effects of terrain age on vegetation characteristics, root density, and ASC

Along both chronosequences, the vegetation characteristics varied across the moraines (Table 3 ). At the Stein Glacier foreland, the plant cover reached its peak on mid-successional moraines $(137 \%$ at 160 a and $125 \%$ at $3 \mathrm{ka}$ moraines; Table 3). At the Griess Glacier foreland, the plant cover was increasing significantly with moraine age (Tukey Test, $\mathrm{p}<0.05$ ). A similar pattern was observed for the Shannon diversity index (Table 3). The highest levels of diversity $(H \approx 2.5$ at 160 a and 3 ka moraines) were observed at the Stein Glacier foreland for the midsuccessional moraines. Conversely, at the Griess Glacier site, the Shannon index was significantly the highest at old moraines $(H \approx 2.3$ at $4.9 \mathrm{ka}$ and
13.5 ka moraines) compared to young moraines $(H \approx 1.7$ at 110 a and 160 a moraine).

At the Stein Glacier foreland, RMD significantly varied across the moraines ranging from $2.5 \mathrm{~kg} \mathrm{~m}^{-3}$ at the 30 a moraine to $17.7 \mathrm{~kg} \mathrm{~m}^{-3}$ at the $10 \mathrm{ka}$ moraine (Table 3). At the Griess Glacier foreland, old moraines (4.9 ka, $13.5 \mathrm{ka}$ ) had significantly higher levels of RMD $\left(\approx 11.5 \mathrm{~kg} \mathrm{~m}^{-3}\right)$ than young moraines $\left(3.1 \mathrm{~kg} \mathrm{~m}^{-3}\right.$ at the $110 \mathrm{a}, 5.3 \mathrm{~kg} \mathrm{~m}^{-3}$ at the 160 a moraine; Table 3). The amount of fine roots $(<1 \mathrm{~mm})$ contributing to total root biomass ranged between 81 and 24\%. Hence, RMD was considerably influenced by coarse roots ( $>1 \mathrm{~mm}$ ) (Table 3$)$.

At Stein Glacier foreland, RLD was highest at mid-successional stages $\left(951 \mathrm{~km} \mathrm{~m}^{-3}\right.$ at the $160 \mathrm{a}, 845 \mathrm{~km} \mathrm{~m}^{-3}$ at the $3 \mathrm{ka}$ moraines; Table 3). At the Griess Glacier site, RLD values of young moraines $\left(110 \mathrm{a}, 160 \mathrm{a} \approx 300 \mathrm{~km} \mathrm{~m}^{-3}\right.$ ) were significantly lower compared to old moraines (4.9 ka, $13.5 \mathrm{ka} \approx 900 \mathrm{~km} \mathrm{~m}^{-3}$ ). Root length was almost exclusively driven by the fine root fraction (Table 3).

ASC values increased with terrain age at both study areas, ranging from 0.33 to 0.97 at Stein Glacier and from 0.23 to 0.92 at Griess Glacier, respectively (Table 3). At the Griess Glacier foreland, the two oldest moraines had significantly higher ASC levels compared to the two youngest moraines. At the 160 a and 3 ka moraines of the Stein Glacier foreland, ASC was significantly higher compared to the 30 a moraine (Tukey Test, $\mathrm{p}<0.05$ ), and significantly lower compared to the 10 ka moraine (Table 3 ).

Table 3 Development of plant cover, Shannon index, Root Mass Density (RMD), Root Length Density (RLD), and Aggregate Stability Coefficient (ASC) along the chronosequences of the two study sites (Stein Glacier, Griess Glacier).

\begin{tabular}{|c|c|c|c|c|c|}
\hline & Cover $[\%]$ & Shannon index & $\mathrm{RMD}\left[\mathrm{kg} / \mathrm{m}^{3}\right]$ & $\operatorname{RLD}\left[\mathrm{km} / \mathrm{cm}^{3}\right]$ & $\mathrm{ASC}[\%]$ \\
\hline \multicolumn{6}{|c|}{ Stein Glacier } \\
\hline $30 \mathrm{a}$ & $84.35 \pm 6.96 \mathrm{a}$ & $2.18 \pm 0.07 \mathrm{ab}$ & $2.50 \pm 0.50 \mathrm{a}(81 \%)$ & $328.38 \pm 62.35 \mathrm{a}(>99 \%)$ & $0.33 \pm 0.04 \mathrm{a}$ \\
\hline $160 \mathrm{a}$ & $137.15 \pm 5.33 b$ & $2.51 \pm 0.08 b$ & $8.75 \pm 1.16 b(64 \%)$ & $950.66 \pm 89.06 b(>99 \%)$ & $0.63 \pm 0.04 b$ \\
\hline $3 \mathrm{ka}$ & $125.48 \pm 3.66 \mathrm{~b}$ & $2.56 \pm 0.04 b$ & $9.91 \pm 0.91 b(83 \%)$ & $845.27 \pm 82.04 b(>99 \%)$ & $0.70 \pm 0.04 b$ \\
\hline $10 \mathrm{ka}$ & $124.96 \pm 1.55 b$ & $2.00 \pm 0.05 \mathrm{a}$ & $17.73 \pm 1.41 \mathrm{c}(24 \%)$ & $372.92 \pm 35.97 \mathrm{a}(>99 \%)$ & $0.97 \pm 0.01 \mathrm{c}$ \\
\hline \multicolumn{6}{|c|}{ Griess Glacier } \\
\hline $110 \mathrm{a}$ & $28.03 \pm 1.30 \mathrm{a}$ & $1.71 \pm 0.06 \mathrm{a}$ & $3.05 \pm 0.97 \mathrm{a}(53 \%)$ & $190.70 \pm 37.56 \mathrm{a}(>99 \%)$ & $0.23 \pm 0.03 \mathrm{a}$ \\
\hline $160 \mathrm{a}$ & $55.59 \pm 6.23 b$ & $1.72 \pm 0.10 \mathrm{a}$ & $5.32 \pm 0.92 \mathrm{a}(49 \%)$ & $210.78 \pm 33.82 \mathrm{a}(>99 \%)$ & $0.36 \pm 0.04 a$ \\
\hline $4.9 \mathrm{ka}$ & $99.69 \pm 3.54 c$ & $2.34 \pm 0.07 b$ & $11.43 \pm 0.96 b(71 \%)$ & $1005.13 \pm 91.41(>99 \%)$ & $0.78 \pm 0.07 b$ \\
\hline $13.5 \mathrm{ka}$ & $122.60 \pm 4.50 \mathrm{~d}$ & $2.39 \pm 0.07 b$ & $11.86 \pm 1.15 b(69 \%)$ & $851.29 \pm 89.40 b(>99 \%)$ & $0.92 \pm 0.02 b$ \\
\hline
\end{tabular}

Mean values of raw data and standard errors $(n=6)$ are given for all moraines. A post-hoc Tukey statistic was used to conduct multiple pairwise comparisons between the moraines of each of the two sites. Significant differences are highlighted with different letters. The fine root fractions of RMD and RLD are given in parentheses 
Table 4 Fixed effect summaries of the Linear Mixed-Effect Models (LMERs)
LMERs were built

according to study hypotheses $(\mathrm{H} 1-\mathrm{H} 5$, for details, see "Introduction" section and Table 2). Marginal $\mathrm{R}^{2}$ for linear mixed effect models was calculated according to Nakagawa and Schielzeth (2013). Effects with $\mathrm{p}<0.05$ are displayed in bold. Predictor variable age was scaled prior to analysis. For details on model assumptions see Fig. 1. Acronyms: ASC = Aggregate Stability Coefficient, RLD = Root Length Density, RMD = Root Mass Density.

\begin{tabular}{|c|c|c|c|c|c|c|c|}
\hline LMER & Response & Fixed effect & Estimate & Std. error & df & t-value & p-value \\
\hline \multirow[t]{5}{*}{ model1 } & RLD & Intercept & 531.103 & 129.207 & 5.02 & 4.11 & 0.009 \\
\hline & $\mathrm{R}^{2}=0.30$ & Stein glacier & 63.985 & 183.097 & 4.99 & 0.35 & 0.741 \\
\hline & & Shannon & 171.717 & 35.919 & 127.69 & 4.78 & $<1 \mathrm{e}-5$ \\
\hline & & age & 126.391 & 90.860 & 4.78 & 1.39 & 0.226 \\
\hline & & Shannon*age & 107.840 & 38.292 & 121.25 & 2.82 & 0.006 \\
\hline \multirow[t]{5}{*}{ model 2} & RLD & Intercept & 381.607 & 220.112 & 14.33 & 1.73 & 0.104 \\
\hline & $\mathrm{R}^{2}=0.16$ & Stein glacier & 6.268 & 238.676 & 5.17 & 0.03 & 0.980 \\
\hline & & Cover & 2.094 & 1.679 & 99.35 & 1.25 & 0.215 \\
\hline & & Age & 99.938 & 205.333 & 32.73 & 0.49 & 0.630 \\
\hline & & Cover*age & 0.256 & 1.562 & 94.95 & 0.16 & 0.870 \\
\hline \multirow[t]{5}{*}{ model 3} & RMD & Intercept & 6.657 & 1.381 & 4.86 & 4.82 & 0.005 \\
\hline & $\mathrm{R}^{2}=0.46$ & Stein glacier & 3.664 & 1.953 & 4.79 & 1.88 & 0.122 \\
\hline & & Shannon & 0.179 & 0.562 & 94.25 & 0.32 & 0.751 \\
\hline & & Age & 4.448 & 0.955 & 4.33 & 4.66 & 0.008 \\
\hline & & Shannon*age & 1.178 & 0.611 & 108.94 & 1.93 & 0.056 \\
\hline \multirow[t]{5}{*}{ model4 } & RMD & Intercept & 7.970 & 1.361 & 6.60 & 5.86 & 0.001 \\
\hline & $\mathrm{R}^{2}=0.49$ & Stein glacier & 0.570 & 1.964 & 7.25 & 0.29 & 0.780 \\
\hline & & Cover & 2.473 & 0.941 & 72.38 & 2.63 & 0.010 \\
\hline & & Age & 3.020 & 1.017 & 8.43 & 2.97 & 0.016 \\
\hline & & Cover*age & 1.093 & 0.858 & 66.21 & 1.28 & 0.207 \\
\hline \multirow[t]{5}{*}{ model5 } & ASC & Intercept & 60.367 & 4.251 & 6.51 & 14.20 & $<1 \mathrm{e}-5$ \\
\hline & $\mathrm{R}^{2}=0.70$ & Stein glacier & 7.597 & 5.821 & 5.74 & 1.31 & 0.242 \\
\hline & & RLD & 6.666 & 1.969 & 68.71 & 3.39 & 0.001 \\
\hline & & Age & 21.394 & 2.926 & 5.7 & 7.31 & $<1 \mathrm{e}-3$ \\
\hline & & RLD*age & -6.752 & 2.135 & 95.65 & -3.16 & 0.002 \\
\hline \multirow[t]{5}{*}{ model6 } & ASC & Intercept & 58.815 & 4.812 & 5.54 & 12.22 & $<1 \mathrm{e}-4$ \\
\hline & $\mathrm{R}^{2}=0.67$ & Stein glacier & 13.277 & 6.628 & 5.00 & 2.00 & 0.183 \\
\hline & & RMD & 5.563 & 2.184 & 113.52 & 2.55 & 0.012 \\
\hline & & Age & 21.207 & 3.623 & 6.93 & 5.85 & 0.001 \\
\hline & & RMD*age & -5.815 & 2.122 & 99.69 & -2.74 & 0.001 \\
\hline \multirow[t]{5}{*}{ model7 } & ASC & Intercept & 54.579 & 5.407 & 5.47 & 10.09 & $<1 \mathrm{e}-4$ \\
\hline & $\mathrm{R}^{2}=0.62$ & Stein glacier & 13.885 & 7.637 & 5.37 & 1.82 & 0.125 \\
\hline & & Shannon & 0.394 & 2.182 & 83.18 & 0.18 & 0.857 \\
\hline & & Age & 24.818 & 3.743 & 4.89 & 6.63 & 0.001 \\
\hline & & Shannon*age & 0.081 & 2.339 & 78.11 & 0.03 & 0.972 \\
\hline \multirow[t]{5}{*}{ model 8} & ASC & Intercept & 60.206 & 4.363 & 6.67 & 13.80 & $<1 \mathrm{e}-5$ \\
\hline & $\mathrm{R}^{2}=0.67$ & Stein glacier & 6.090 & 6.077 & 6.18 & 1.00 & 0.354 \\
\hline & & Cover & 5.105 & 2.858 & 38.58 & 1.79 & 0.082 \\
\hline & & Age & 22.203 & 3.017 & 6.26 & 7.36 & $<1 \mathrm{e}-3$ \\
\hline & & Cover*age & -3.929 & 2.801 & 45.04 & -1.40 & 0.168 \\
\hline
\end{tabular}

ASC as a function of vegetation characteristics and root density

LMERs showed that the Shannon index was a significant predictor of RLD (model 1: $\mathrm{p}<0.001$ ) and that vegetation cover was a significant predictor of RMD (model 4: $p<0.05$, Table 4; Fig. 4) For model 1 , the interaction of terrain age and Shannon index was identified as a significant predictor of RLD showing increasing effect sizes with terrain age (model 1: $\mathrm{p}<0.05, R^{2}=0.30$ ). Similarly, for model 3 the effect sizes increased with moraine 
(a) model1: RLD Shannon*age

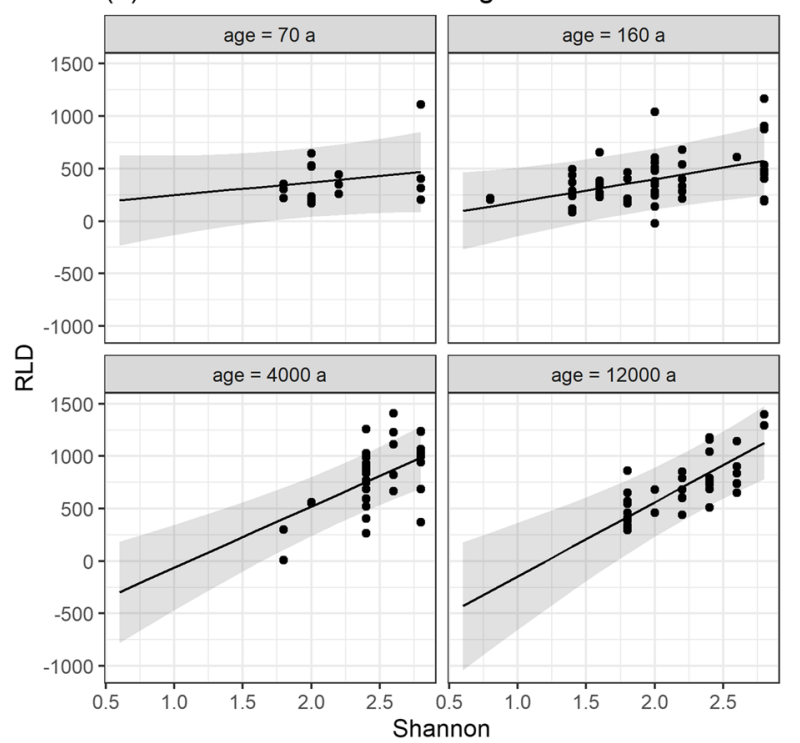

(c) model3: RMD Shannon*age

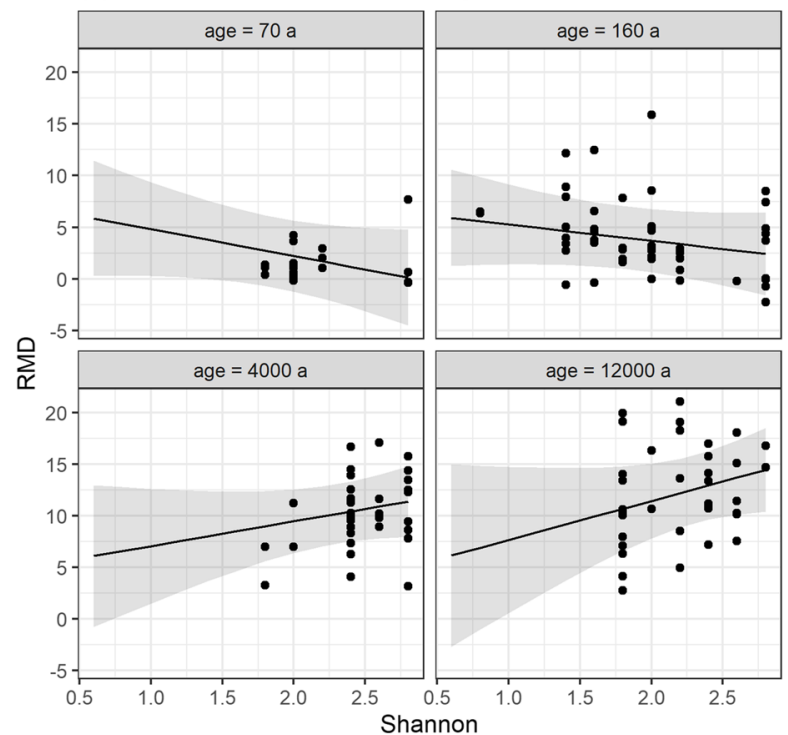

Fig. 4 Effects of Shannon index and egetation cover on root length density [RLD, (a), (b)] and root mass density [RMD, (c), (d)] for various terrain ages. The effect plots of the mixed models 1-4 listed in Table 2 are shown. The predictor variables were displayed for four distinct terrain ages [70 a (=years), $160 \mathrm{a}, 4000 \mathrm{a}, 12000 \mathrm{a}]$ that represented mean ter-

age. For models 2 and 4 illustrating the relationship between vegetation cover, terrain age, and RMD, the interaction term was not significant. (b) model2: RLD cover*age

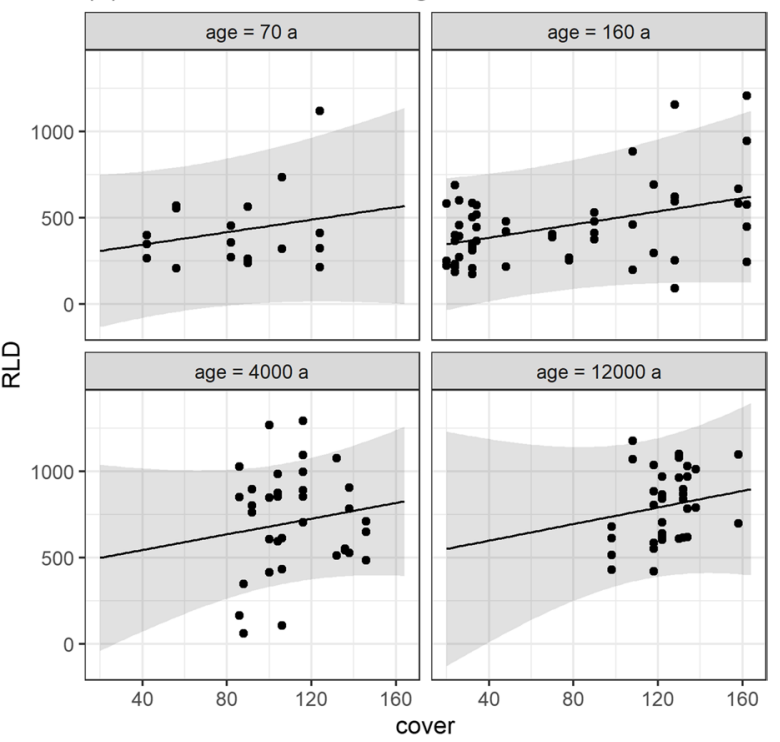

(d) model4: RMD cover*age

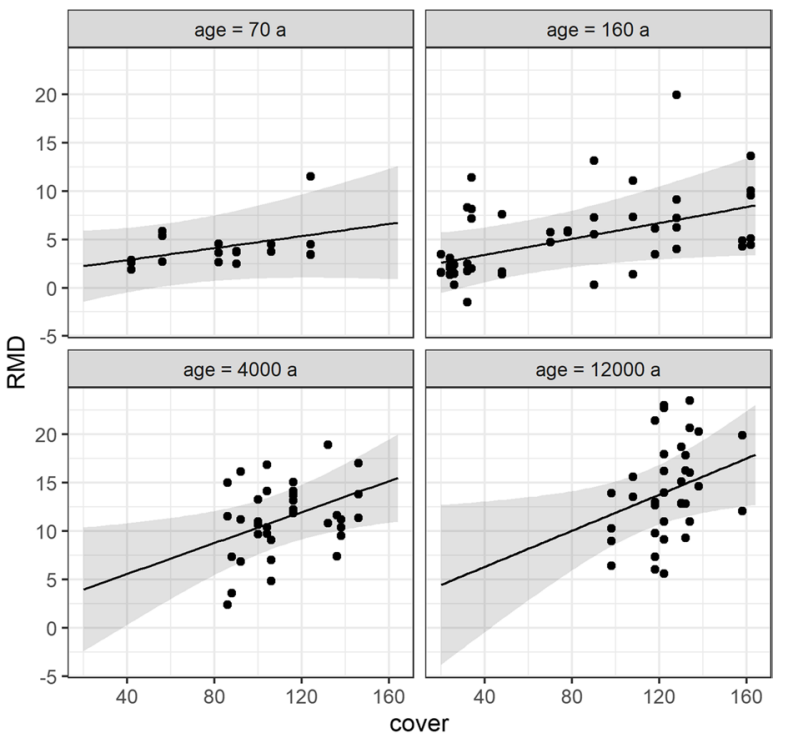

rain ages for each pair of moraines of the two study sites [e.g. mean of the two youngest moraines, Stein Glacier (30 a) and Griess Glacier (110 a), which is 70 a]. The black lines represent the model predictions and the black shades are the 95\% confidence intervals. The black points are the partial residuals of the models.

RLD and RMD were both significantly positively affecting ASC (models 5 and 6, Table 4, Fig. 5). Moreover, the interaction term including terrain age was a 
(a) model5: ASC $\sim$ RLD*age

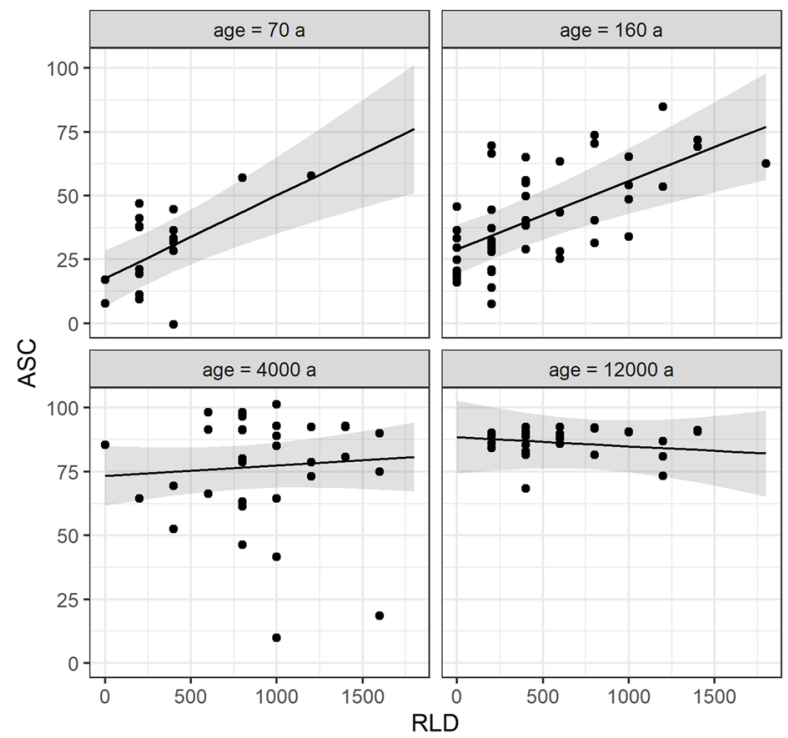

(c) model7: ASC $\sim$ Shannon*age

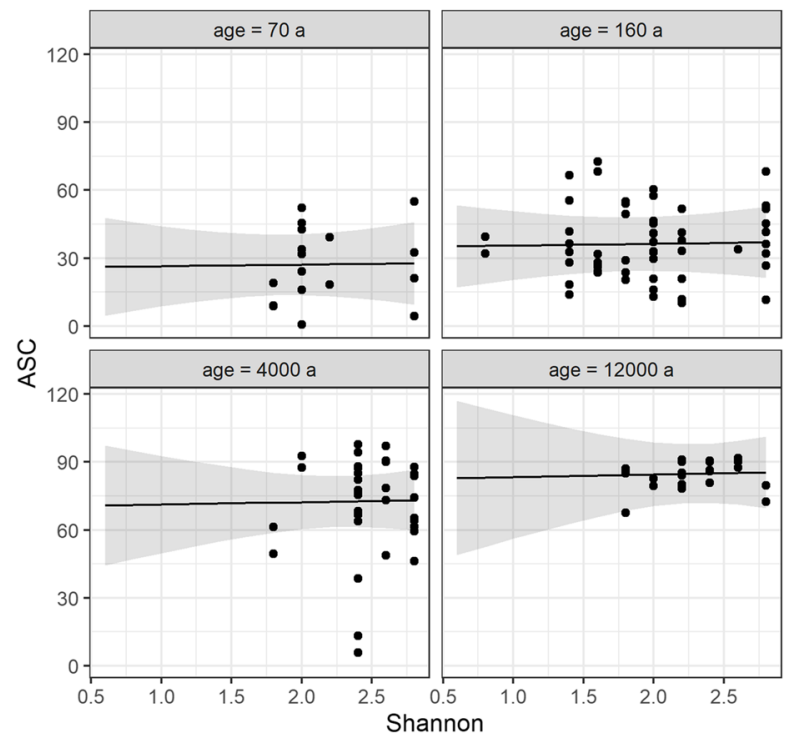

Fig. 5 Effects of root length density [RLD, (a)], root mass density [RMD, (b)], Shannon index (c) and and vegetation cover (d) on soil aggregate stability (ASC) for various terrain ages. The effect plots of the mixed models 1-4 listed in Table 2 are shown. The predictor variables were displayed for four distinct terrain ages [70 a (=years), $160 \mathrm{a}, 4000 \mathrm{a}, 12000 \mathrm{a}$ ] that

significant predictor in both models showing decreasing effect sizes with terrain age (model 5: $\mathrm{p}=0.002$, $\mathrm{R}^{2}=0.70$; model 6: $\mathrm{p}=0.001, \mathrm{R}^{2}=0.67$ ). (b) model6: ASC $\sim \mathrm{RMD}^{*}$ age

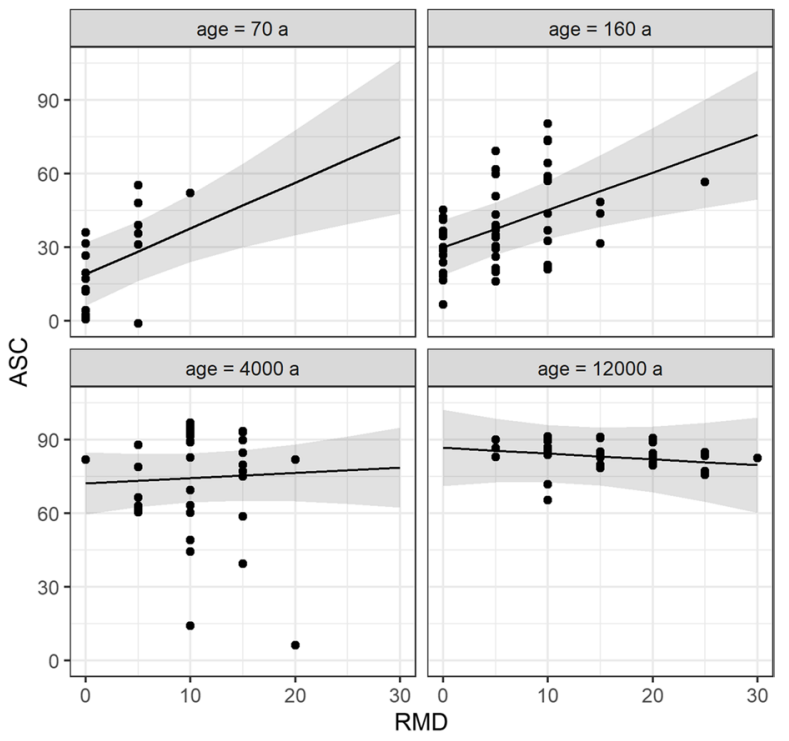

(d) model8: ASC $\sim$ cover $^{*}$ age

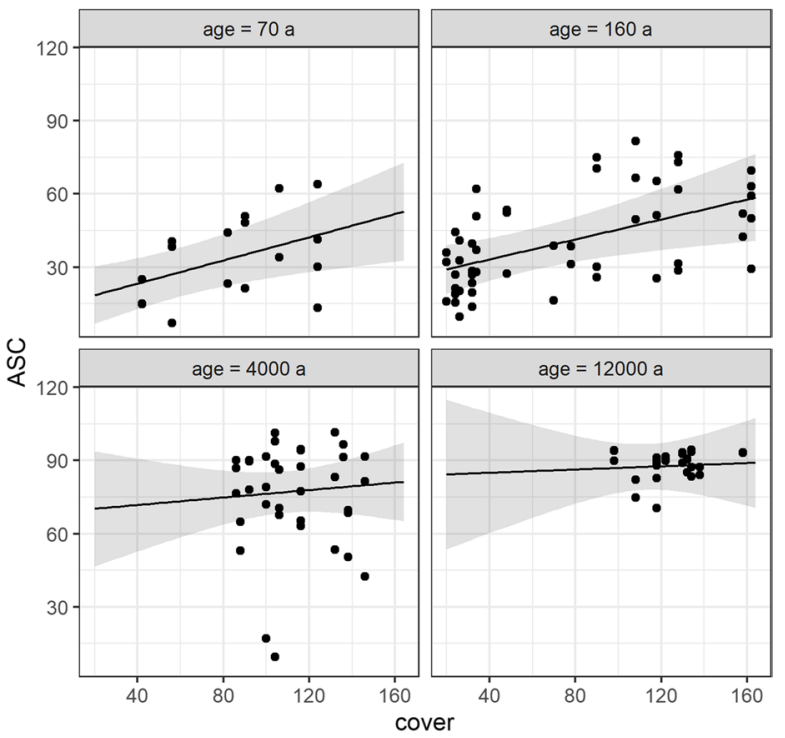

represented mean terrain ages for each pair of moraines of the two study sites (e.g. mean of the two youngest moraines, Stein Glacier Pass (30 a) and Griess Glacier (110 a), which is 70 a). The black lines are the model predictions and the blue shades are the $95 \%$ confidence intervals. The black points are the partial residuals of the models.

Testing the independent effects of plant cover and diversity on ASC, no significant relationship could be detected (Table 4; Fig. 5). However, the interaction effect of cover 
(a) Terrain age $\leq 160 a$

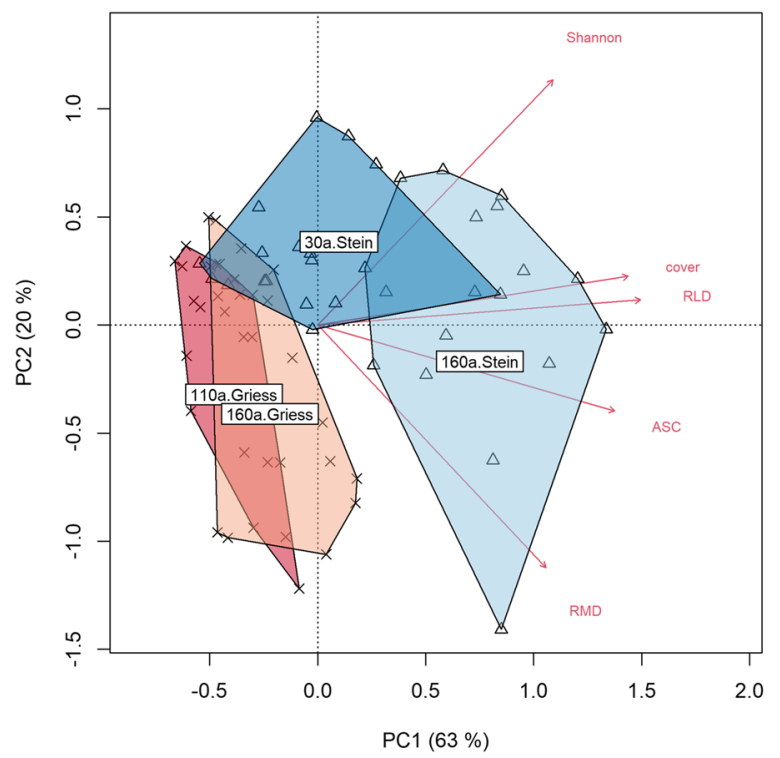

Fig. 6 Principal Component Analysis (PCA) of variables related to soil aggregate stability for moraines $\leq 160$ a (a) and for moraines $\geq 3 \mathrm{ka}(\mathbf{b})$. Correlations of the variables with principal components (PC1, PC2) are indicated by length and direction of arrows. The affiliation of the single observations to

and terrain age was indicated resulting in decreasing effect sizes with terrain age (model 8: $\mathrm{p}=0.17, \mathrm{R}^{2}=0.67$ ).

Because LMERs suggested different relationships between ASC and vegetation parameters (Fig. 5), we grouped the dataset into young $(\leq 160$ a) and old $(\geq 3 \mathrm{ka}$ ) moraines and performed separate PCAs on each subset. Both PCAs showed two principal components with an eigenvalue larger than 1 . The first two axes accounted for $83.27 \%$ (Fig. 6a) and $59.58 \%$ (Fig. 6b) to total inertia. The multivariate analyses revealed that ASC was more closely related to RLD on young terrain (Fig. 6a), whereas later during landscape evolution RMD seemed to be more important for ASC development (Fig. 6b).

As with the PCAs, SEMs were performed on young and old moraines separately. Both SEMs adequately fit the data on aggregate stability for the moraines with terrain ages $\leq 160 \mathrm{a} \quad\left(\chi^{2}=1.17\right.$, $\mathrm{P}=0.28 ; \quad \mathrm{AIC}=265.03 ; \quad \mathrm{RMSEA} \leq 0.05$, Fig. 7a) and for the moraines $\geq 3 \mathrm{ka}\left(\chi^{2}=0.25, \mathrm{P}=0.62\right.$; $\mathrm{AIC}=314.49$; RMSEA $<0.001$, Fig. 7b) (standardized path coefficients are given in Fig. 7). Similarly, to the results of the PCAs we found that RLD increased ASC on young terrain, whereas RMD (b) Terrain age $\geq 3 k a$

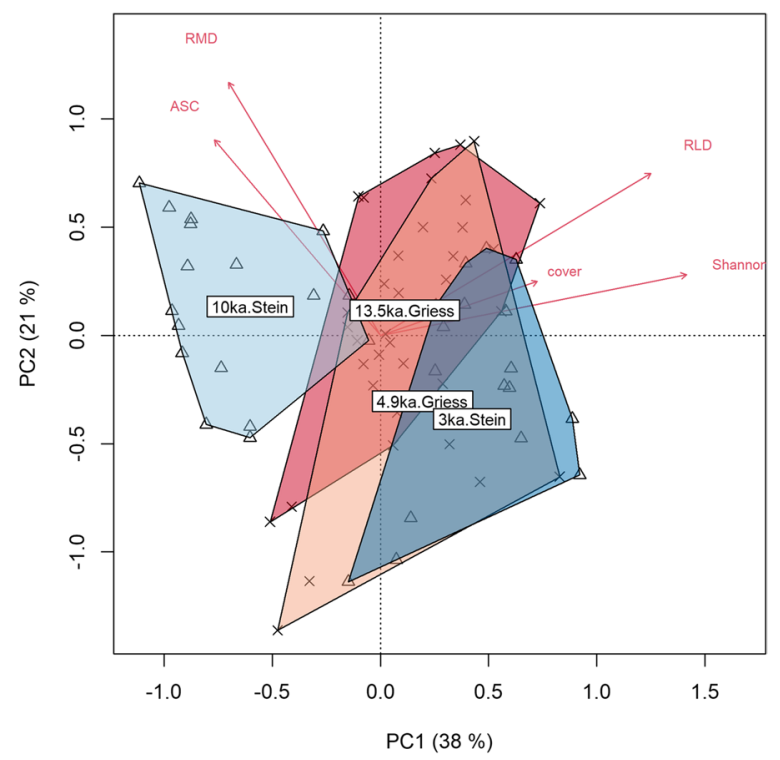

the moraines is shown by the polygons. Triangulars belong to the Stein Glacier and crosses to the Griess Glacier. Acronyms: ASC $=$ Aggregate Stability Coefficient, RLD = Root Length Density, RMD = Root Mass Density

was the more important variable for ASC on older moraines (Fig. 7).

\section{Discussion}

Effects of parent material and terrain age on vegetation characteristics and soil aggregate stability

As ASC generally increased positively with terrain age, this study supports the hypothesis that soil aggregate stability increases with progressing vegetation and soil development (Amezketa 1999). Soil development (i.e. the weathering of primary minerals, accumulation of organic matter, and the formation of secondary minerals) generally progresses at high rates in young soils and slows down after several centuries or millennia (Egli et al. 2001; Sauer 2015). Due to an increasing vegetation cover and increased above- and belowground biomass production with terrain age, the organic matter content of the topsoil increases as well (Burga et al. 2010; D'Amico et al. 2014). This was also confirmed by Musso et al. (2019) who found strong changes in 
(a) Terrain age $\leq 160 a$

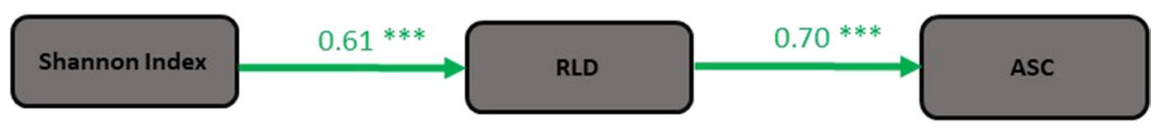

(b) Terrain age $\geq 3 \mathrm{ka}$

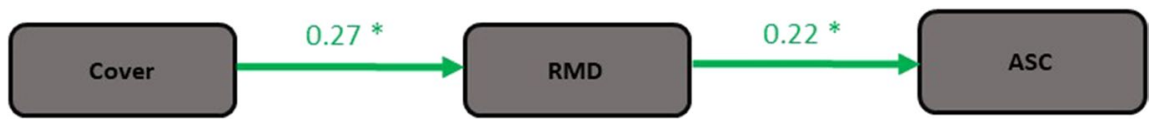

Fig. 7 Structural equation models of vegetation effects on aggregate stability (ASC) in alpine glacier forelands for moraines $\leq 160$ a (a) and for moraines $\geq 3 \mathrm{ka} \mathrm{(b).} \mathrm{Numbers} \mathrm{on}$ arrows are standardized path coefficients (equivalent to correlation coefficients). Asteriscs mark significant relationships (***: p-value $<0.001$, *: p-value $<0.05$ ). The initial models were build based on the study hypotheses and the results

the soil properties at the early stages of soil development at both Stein Glacier and Griess Glacier. However, such processes in soil development are expected to differ with geology. Carbonate-rich parent material weathers mainly by the dissolution of solid carbonates, which buffers soil $\mathrm{pH}$ in the neutral range, thereby slowing down chemical weathering processes (Egli et al. 2008). As a consequence, the accumulation of aggregate-forming clay minerals (Amezketa 1999) might be reduced, which could be an explanation for the lower ASC levels found at the youngest two moraines of the Griess Glacier site compared to the Stein Glacier site.

Furthermore, higher levels of vegetation cover prevent soil weathering products from being washed away by rainfall, thereby increasing the relative amount of fine soil particles (Burri et al. 2009). The organic compounds and the fine soil particles form micro-aggregates, mainly shaped and stabilized by plant roots and microorganisms (Amezketa 1999; Rillig and Mummey 2006; Tisdall and Oades 1982). The soil aggregates modify the soil structure and enhance the water and nutrient retention capacity of the soil, thereby again benefitting root growth and plant performance (Miller et al. 2002; Pohl et al. 2012). of the LMERs (f1: ASC $\sim$ RLD + RMD, f2: RLD Shannon Index, f3: RMD Cover). The results were the simplified until adequate fit was achieved. $\mathbf{a} \chi^{2}=1.17, \mathrm{P}=0.28 ; \mathrm{AIC}=265.03$; RMSEA $=<0.05 ; \quad$ b $\quad \chi^{2}=0.25, \quad \mathrm{P}=0.62 ; \quad \mathrm{AIC}=314.49$; RMSEA $<0.001$. Acronyms: ASC $=$ Aggregate Stability Coefficient, RLD = Root Length Density, RMD = Root Mass Density

The effect of vegetation characteristics on ASC is mediated via root density

Shannon diversity index and plant cover showed a positive correlation with root density, and thus we could confirm our first hypothesis assuming that plant community characteristics affect root density. A high species richness might increase the probability that plant species with deeper or denser root systems or higher biomass production occur ("selection effect" sensu Loreau and Hector 2001, see also Tilman et al. 2014, Garnier et al. 2016), which would then largely control the effects of vegetation on ASC and soil stability. In addition, higher plant diversity offers the possibility that the available soil volume might be more densely occupied by roots due to niche partitioning and subsequent resource use complementarity ("complementarity effect"). We found evidence that the effect of plant diversity on root density was getting stronger with terrain age. Similar results were found by Ravenek et al. (2014) who detected an increasing correlation between plant species richness and belowground productivity with time. A reason might be that during succession not only the total species number but also the number of highly productive and competitive species increases (Walker and del Moral 2003). This potentially enhances belowground 
complementarity effects leading to an increase of root productivity with terrain age.

Testing the second hypothesis showed that RLD and RMD had a significant positive effect on the ASC, whereby the correlation weakened with increasing age. Such positive effects support the current view that roots are one of the main drivers of soil aggregate stability (Bardgett et al. 2014; Pohl et al. 2009; Reubens et al. 2007). Roots are a crucial part of the soil-forming processes mentioned in the previous section such as weathering and accumulation of organic matter. They contribute to increasing stability by mechanisms such as particle binding through root exudates and also physically stabilize the soil in the form of cohesive strength. Thereby, fine roots are more important than coarse roots for soil processes that directly depend on the physiological interactions between plants and soil, such as the formation of soil aggregates and nutrient cycling (Bardgett et al. 2014; Loades et al. 2010; McCormack et al. 2015). Our results highlight that the measured root characteristics are useful for predicting soil aggregate stability.

The third hypothesis addressed the direct impact of aboveground vegetation and diversity on ASC. Although our data did not provide statistically significant evidence for a direct effect of plant cover and diversity on ASC, we could clearly show that these parameters influenced root density, and those, in turn, drove ASC. We thus conclude that the effect of cover and diversity on ASC is mediated via root density. However, on young moraines, plant cover positively influenced ASC. This finding is in accordance with Pohl et al. (2012) who showed that species richness, vegetation cover, and root density were positively related to ASC at disturbed alpine slopes. Therefore, plant cover might not only have an indirect impact on ASC through roots but it could be also beneficial in itself (Cerdà 1998; Pohl et al. 2012). It reduces hydrological sediment transport and soil erosion on hillslopes induced by raindrop splash and surface runoff (Geißler et al. 2012; Goebes et al. 2015; Poesen 2018; Vannoppen et al. 2015). Furthermore, plant cover protects the surface from wind erosion and collects wind-blown silt, which enhances soil development as well as aggregate formation (Gyssels et al. 2005; Walker and del Moral 2003).

ASC predictions change with terrain age: link to the concept of geomorphic succession

The importance of the different predictor variables for ASC changed with terrain age (hypothesis 4). On older moraines, the impact of root density on ASC was weakened. Instead, species diversity was positively related to root biomass at those habitats. Such diverse alpine grassland biotopes are known to produce very stable hillslopes as described by Körner and Spehn (2002), picturing root systems of speciesrich slopes as the screws and nails of various forms and sizes in alpine soils. On young surfaces, patches with high plant cover and high root density had the highest ASC levels. The results of the LMERs indicate that rather cover than diversity affected ASC at early stages of soil formation suggesting that species identity was a stronger driver than species diversity. Moreover, we found evidence that RLD, which is linked to direct interactions at the root-soil interface, was the more important variable early during succession. Instead, on older moraines, RMD was a stronger driver of ASC suggesting that the accumulation of SOM is an important process for hillslope stability in the long term. On young surfaces, matforming species such as the creeping dwarf shrubs Salix retusa and Dryas octopetala build microhabitats with enhanced organic matter accumulation and microbial activity due to their dense rootstocks (Bjorbækmo et al. 2010). Thus, in early-successional glacier foreland habitats, soil formation seems to develop initially from separate patches of ecosystemengineering species (Eichel et al. 2013; Eichel 2019). This applies to the concept of biogeomorphic succession, which is a sequence of three biogeomorphic phases forming a gradient of decreasing geomorphic and increasing ecological importance (Corenblit et al. 2007). In the pioneer phase, high geomorphic activity is assumed and only pioneer species adapted to the dominant geomorphic processes occur. In the biogeomorphic phase, geomorphic activity is lower and community composition is dominated by dwarf shrubs acting as geomorphic-engineering species. In the ecological phase, autecological processes such as competition prevail and geomorphic-engineering species are missing (Eichel et al. 2013). In light of this concept, the major changes in ASC development of this study could be attributed to the biogeomorphic phase where the strongest interactions of geomorphic and ecological processes are expected. The results of the present study suggest that this phase is crucial for the development of hillslope functioning and that important biogeomorphological processes, such as 
biostabilisation or bioaccumulation (Corenblit et al. 2011), change during this phase.

\section{Conclusion}

To our knowledge, this is the first study to investigate the development of ASC along alpine chronosequences by quantifying its interrelations with various vegetation characteristics. The results highlight that root density plays a major role in governing ASC on moraines of different substrate exposure. We show evidence that the effect of vegetation cover and Shannon index on ASC is mediated via root density. These relationships are most pronounced on young surfaces where engineering species create patches with high biogeomorphic activity.

As our study focused on the biotic factors, we encourage further research to include the impact of soil and hydrological parameters on ASC development. Especially for modelling ASC development, future research should take into account the grain size distribution as patches with high silt or clay content might be crucial for the initial aggregate formation on young surfaces. Furthermore, for a better understanding of the development of hillslope stability, it is important to measure further soil aggregate related parameters such as aggregate size and aggregate amount. Finally, in order to more mechanistically unravel the direct plantsoil interactions affecting aggregate stability at the hillslope scale the in-situ quantification of mycorrhiza and root exudates should be considered.

Acknowledgements We want to thank Thomas Michel and his team of the Alpin Center Sustenpass as well as Cècile Zemp from Hotel Klausenpasshöhe for accommodation and logistic support during the fieldwork. We further thank Alexander Bast for explanations on measuring ASC, Holger Gärtner for providing equipment for the field work and Laura Rose for advice on the experimental setup. We thank Carsten Dormann for advice on the statistical approach.

Author contributions TG, LT, MSL and KG conceived the research idea; LT, VK, and KG collected the data; VK and $\mathrm{KG}$ performed statistical analyses; KG, with contributions from TG, LT, VK, AM, FM, FL, and MSL, wrote the paper; all authors discussed the results and commented on the manuscript.

Funding Open Access funding enabled and organized by Projekt DEAL. This research is part of the HILLSCAPE project (www.hillscape.ch), which is supported by the German
Research Foundation (DFG Project No. 318089487, funding to MSL: SCHE 695/9-1) and the Swiss National Science Foundation (Project Grant No. 200021E-167563/1).

Data availability The datasets generated and analyzed during the current study are available from the corresponding author on reasonable request.

Code availability The $\mathrm{R}$ Code is available from the corresponding author on reasonable request.

\section{Declarations}

Conflict of interest We certify that there is no actual or potential conflict of interest in relation to this article.

Ethical approval We certify that there is no actual or potential conflict with the ethical standards in relation to this article.

Open Access This article is licensed under a Creative Commons Attribution 4.0 International License, which permits use, sharing, adaptation, distribution and reproduction in any medium or format, as long as you give appropriate credit to the original author(s) and the source, provide a link to the Creative Commons licence, and indicate if changes were made. The images or other third party material in this article are included in the article's Creative Commons licence, unless indicated otherwise in a credit line to the material. If material is not included in the article's Creative Commons licence and your intended use is not permitted by statutory regulation or exceeds the permitted use, you will need to obtain permission directly from the copyright holder. To view a copy of this licence, visit http://creativecommons.org/licenses/by/4.0/.

\section{References}

Amezketa E (1999) Soil aggregate stability: a review. J Sustain Agric 14:83-151. https://doi.org/10.1300/J064v14n02_08

Anache JA, Flanagan DC, Srivastava A, Wendland EC (2018) Land use and climate change impacts on runoff and soil erosion at the hillslope scale in the Brazilian Cerrado. Sci Total Environ 622-623:140-151. https://doi.org/10. 1016/j.scitotenv.2017.11.257

Bardgett RD, Mommer L, de Vries FT (2014) Going underground: root traits as drivers of ecosystem processes. Trends Ecol Evol 29:692-699. https://doi.org/10.1016/j. tree.2014.10.006

Bast A, Wilcke W, Graf F, Lüscher P, Gärtner H (2014) The use of mycorrhiza for eco-engineering measures in steep alpine environments: effects on soil aggregate formation and fine-root development. Earth Surf Proc Landf 39:1753-1763. https://doi.org/10.1002/esp.3557

Bast A, Wilcke W, Graf F, Lüscher P, Gärtner H (2015) A simplified and rapid technique to determine an aggregate stability coefficient in coarse grained soils. CATENA 127:170-176. https://doi.org/10.1016/j.catena.2014.11.017

Bast A, Wilcke W, Graf F, Lüscher P, Gärtner H (2016) Does mycorrhizal inoculation improve plant survival, aggregate 
stability, and fine root development on a coarse-grained soil in an alpine eco-engineering field experiment? J Geophys Res Biogeosci 121:2158-2171. https://doi.org/10. 1002/2016JG003422

Bates D, Sarkar D, Bates MD, Matrix L (2007) The lme4 package. R Package Version 2:74

Bjorbækmo MFM, Carlsen T, Brysting A, Vrålstad T, Høiland K, Ugland KI, Geml J, Schumacher T, Kauserud H (2010) High diversity of root associated fungi in both alpine and arctic Dryas octopetala. BMC Plant Biol 10:244. https:// doi.org/10.1186/1471-2229-10-244

Blume H-P, Brümmer GW, Horn R, Kandeler E, Kögel-Knabner I, Kretzschmar R, Stahr K, Wilke B-M, Thiele-Bruhn S, Welp G (2010) Scheffer/Schachtschabel. Lehrbuch Der Bodenkunde. https://doi.org/10.1007/978-3-642-30942-7

Bronick CJ, Lal R (2005) Soil structure and management: a review. Geoderma 124:3-22. https://doi.org/10.1016/j. geoderma.2004.03.005

Burga CA, Krüsi B, Egli M, Wernli M, Elsener S, Ziefle M, Fischer T, Mavris C (2010) Plant succession and soil development on the foreland of the Morteratsch glacier (Pontresina, Switzerland): straight forward or chaotic? Flora 205:561-576. https://doi.org/10.1016/j.flora.2009. 10.001

Burri K, Graf F, Böll A (2009) Revegetation measures improve soil aggregate stability: a case study of a landslide area in Central Switzerland. Forest Snow Landsc Res 82:45-60

Burylo M, Rey F, Mathys N, Dutoit T (2012) Plant root traits affecting the resistance of soils to concentrated flow erosion. Earth Surf Proc Landf 37:1463-1470. https://doi. org/10.1002/esp.3248

Canarini A, Kaiser C, Merchant A, Richter A, Wanek W (2019) Root exudation of primary metabolites: mechanisms and their roles in plant responses to environmental stimuli. Front Plant Sci 10:157. https://doi.org/10.3389/ fpls.2019.00157

Cerdà A (1998) Soil aggregate stability under different Mediterranean vegetation types. CATENA 32:73-86

Corenblit D, Tabacchi E, Steiger J, Gurnell AM (2007) Reciprocal interactions and adjustments between fluvial landforms and vegetation dynamics in river corridors: a review of complementary approaches. Earth Sci Rev 84:56-86. https://doi.org/10.1016/j.earscirev.2007.05.004

Corenblit D, Baas AC, Bornette G, Darrozes J, Delmotte S, Francis RA, Gurnell AM, Julien F, Naiman RJ, Steiger J (2011) Feedbacks between geomorphology and biota controlling Earth surface processes and landforms: a review of foundation concepts and current understandings. Earth Sci Rev 106:307-331. https://doi.org/10.1016/j.earscirev. 2011.03.002

D’Amico ME, Freppaz M, Filippa G, Zanini E (2014) Vegetation influence on soil formation rate in a proglacial chronosequence (Lys Glacier, NW Italian Alps). CATENA 113:122-137. https://doi.org/10.1016/j.catena.2013.10. 001

Duan L, Sheng H, Yuan H, Zhou Q, Li Z (2021) Land use conversion and lithology impacts soil aggregate stability in subtropical China. Geoderma 389:114953. https://doi.org/ 10.1016/j.geoderma.2021.114953

Egli M, Fitze P, Mirabella A (2001) Weathering and evolution of soils formed on granitic, glacial deposits: results from chronosequences of Swiss alpine environments. CATENA 45:19-47. https://doi.org/10.1016/S0341-8162(01) 00138-2

Egli M, Merkli C, Sartori G, Mirabella A, Plötze M (2008) Weathering, mineralogical evolution and soil organic matter along a Holocene soil toposequence developed on carbonate-rich materials. Geomorphology 97:675-696. https://doi.org/10.1016/j.geomorph.2007.09.011

Eichel J (2019) Vegetation succession and biogeomorphic interactions in Glacier Forelands. In: Heckmann T, Morche D (eds) Geomorphology of proglacial systems: landform and sediment dynamics in recently deglaciated alpine landscapes. Springer International Publishing, Cham, pp 327-349

Eichel J, Krautblatter M, Schmidtlein S, Dikau R (2013) Biogeomorphic interactions in the Turtmann glacier forefield, Switzerland. Geomorphology 201:98-110. https:// doi.org/10.1016/j.geomorph.2013.06.012

Erktan A, Cécillon L, Graf F, Roumet C, Legout C, Rey F (2015) Increase in soil aggregate stability along a Mediterranean successional gradient in severely eroded gully bed ecosystems: combined effects of soil, root traits and plant community characteristics. Plant Soil 398:121-137. https://doi.org/10.1007/s11104-015-2647-6

Eshel A, Beeckman T (2013) Plant roots: the hidden half. CRC Press, Boca Raton

Food and Agriculture Organization of the United Nations, Romeo R, Vita A, Manuelli S, Zanini E, Freppaz M, Stanchi S (2015) Understanding mountain soils: a contribution from mountain areas to the International year of soils 2015. FAO, Rome

Fox J, Weisberg S (2018) Visualizing fit and lack of fit in complex regression models with predictor effect plots and partial residuals. J Stat Softw 87:1-27

Garnier E, Navas M-L, Grigulis K (2016) Plant functional diversity. Organism traits, community structure, and ecosystem properties, 1st edn. Oxford University Press, Oxford

Geißler C, Kühn P, Böhnke M, Bruelheide H, Shi X, Scholten $\mathrm{T}$ (2012) Splash erosion potential under tree canopies in subtropical SE China. CATENA 91:85-93. https://doi.org/ 10.1016/j.catena.2010.10.009

Gobiet A, Kotlarski S, Beniston M, Heinrich G, Rajczak J, Stoffel M (2014) 21st century climate change in the European Alps-a review. Sci Total Environ 493:1138-1151. https://doi.org/10.1016/j.scitotenv.2013.07.050

Goebes P, Bruelheide H, Härdtle W, Kröber W, Kühn P, Li Y, Seitz S, von Oheimb G, Scholten T (2015) Species-specific effects on throughfall kinetic energy in subtropical forest plantations are related to leaf traits and tree architecture. PLoS ONE 10:e0128084. https://doi.org/10.1371/ journal.pone. 0128084

Grace JB (2006) Structural equation modeling and natural systems. Cambridge University Press, Cambridge

Gyssels G, Poesen J, Bochet E, Li Y (2005) Impact of plant roots on the resistance of soils to erosion by water: a review. Prog Phys Geogr 29:189-217. https://doi.org/10. 1191/0309133305pp443ra

Hudek C, Stanchi S, D’Amico M, Freppaz M (2017a) Quantifying the contribution of the root system of alpine vegetation in the soil aggregate stability of moraine. J Soil Water 
Conserv 5:36-42. https://doi.org/10.1016/j.iswcr.2017.02. 001

Hudek C, Sturrock CJ, Atkinson BS, Stanchi S, Freppaz M (2017b) Root morphology and biomechanical characteristics of high altitude alpine plant species and their potential application in soil stabilization. Ecol Eng 109:228-239

Kervroëdan L, Armand R, Saunier M, Faucon M-P (2019) Effects of plant traits and their divergence on runoff and sediment retention in herbaceous vegetation. Plant Soil 441:511-524. https://doi.org/10.1007/ s11104-019-04142-6

Kervroëdan L, Armand R, Rey F, Faucon M-P (2021) Traitbased sediment retention and runoff control by herbaceous vegetation in agricultural catchments: a review. Land Degrad Dev 32:1077-1089. https://doi.org/10. 1002/ldr.3812

Körner C, Spehn EM (2002) Mountain biodiversity: a global assessment. Routledge, Abingdon-on-Thames

Kuznetsova A, Brockhoff PB, Christensen RHB (2017) lmerTest package: tests in linear mixed effects models. J Stat Softw 82:1-26

Lauber K, Wagner G, Gygax A (2018) Flora Helvetica, 6th edn. Haupt Verlag, Bern

Liu J, Gao G, Wang S, Jiao L, Wu X, Fu B (2018) The effects of vegetation on runoff and soil loss: multidimensional structure analysis and scale characteristics. J Geog Sci 28:59-78. https://doi.org/10.1007/s11442-018-1459-z

Loades KW, Bengough AG, Bransby MF, Hallett PD (2010) Planting density influence on fibrous root reinforcement of soils. Ecol Eng 36:276-284. https://doi.org/10.1016/j. ecoleng.2009.02.005

Loreau M, Hector A (2001) Partitioning selection and complementarity in biodiversity experiments. Nature 412:72-76. https://doi.org/10.1038/35083573

Lüdi W (1958) Beobachtungen über die Besiedlung von Gletschervorfeldern in den Schweizeralpen. Flora 146:386-407. https://doi.org/10.1016/S0367-1615(17) 32526-0

Lustenberger F (2019) Event-based surface hydrological connectivity and sediment transport on young moraines. MSc Thesis, University of Zürich

Maier F, van Meerveld I, Greinwald K, Gebauer T, Lustenberger F, Hartmann A, Musso A (2020) Effects of soil and vegetation development on surface hydrological properties of moraines in the Swiss Alps. CATENA 187:1-17. https://doi.org/10.1016/j.catena.2019.104353

Márquez CO, Garcia VJ, Cambardella CA, Schultz RC, Isenhart TM (2004) Aggregate-size stability distribution and soil stability. Soil Sci Soc Am J 68:725-735. https://doi. org/10.2136/sssaj2004.7250

Martin C, Pohl M, Alewell C, Körner C, Rixen C (2010) Interrill erosion at disturbed alpine sites: effects of plant functional diversity and vegetation cover. Basic Appl Ecol 11:619-626

McCormack ML, Dickie IA, Eissenstat DM, Fahey TJ, Fernandez CW, Guo D, Helmisaari H-S, Hobbie EA, Iversen CM, Jackson RB, Leppälammi-Kujansuu J, Norby RJ, Phillips RP, Pregitzer KS, Pritchard SG, Rewald B, Zadworny M (2015) Redefining fine roots improves understanding of below-ground contributions to terrestrial biosphere processes. New Phytol 207:505518. https://doi.org/10.1111/nph.13363

Meteo Swiss (2016) Swiss Federal Office of meteorology and climatology. Swiss climate in detail. Climate diagrams. Norm values tables. Available at https://www.meteo swiss.admin.ch/product/output/climate-data/climatediagrams-normal-values-station-processing/GRH/clims heet_GRH_np8110_e.pdf

Meusburger K, Alewell C (2014) Soil erosion in the Alps. Experience gained from case studies. Environmental studies. Federal Office for the Environment, Bern

Miller RM, Miller SP, Jastrow JD, Rivetta CB (2002) Mycorrhizal mediated feedbacks influence net carbon gain and nutrient uptake in Andropogon gerardii. New Phytol 155:149-162. https://doi.org/10.1046/j.1469-8137.2002. 00429.x

Musso A, Lamorski K, Sławiński C, Geitner C, Hunt A, Greinwald K, Egli M (2019) Evolution of soil pores and their characteristics in a siliceous and calcareous proglacial area. CATENA 182:1-16. https://doi.org/10.1016/j.catena.2019.104154

Musso A, Ketterer M, Greinwald K, Geitner C, Egli M (2020) Rapid decrease of soil erosion rates with soil formation and vegetation development in periglacial areas. Earth Surf Process Landf 45:2824-2839. https://doi.org/10. 1002/esp.4932

Nakagawa S, Schielzeth H (2013) A general and simple method for obtaining R2 from generalized linear mixed-effects models. Methods Ecol Evol 4:133-142. https://doi.org/10. 1111/j.2041-210x.2012.00261.x

Nearing MA, Pruski FF, O’Neal MR (2004) Expected climate change impacts on soil erosion rates: a review. J Soil Water Conserv 59:43-50

Oechslin M (1935) Beitrag zur Kenntnis der pflanzlichen Besiedelung der durch Gletscher freigegebenen Grundmoränenböden. Berichte Der Naturforschenden Gesellschaft Uri 4:27-48

Pérès G, Cluzeau D, Menasseri S, Soussana JF, Bessler H, Engels C, Habekost M, Gleixner G, Weigelt A, Weisser WW, Scheu S, Eisenhauer N (2013) Mechanisms linking plant community properties to soil aggregate stability in an experimental grassland plant diversity gradient. Plant Soil 373:285-299. https://doi.org/10.1007/ s11104-013-1791-0

Pielou EC (1966) Shannon's formula as a measure of specific diversity: its use and misuse. Am Nat 100:463-465. https://doi.org/10.1086/282439

Poesen J (2018) Soil erosion in the anthropocene: research needs. Earth Surf Proc Landf 43:64-84. https://doi.org/10. 1002/esp.4250

Pohl M, Alig D, Körner C, Rixen C (2009) Higher plant diversity enhances soil stability in disturbed alpine ecosystems. Plant Soil 324:91-102. https://doi.org/10.1007/ s11104-009-9906-3

Pohl M, Stroude R, Buttler A, Rixen C (2011) Functional traits and root morphology of alpine plants. Ann Bot 108:537-545

Pohl M, Graf F, Buttler A, Rixen C (2012) The relationship between plant species richness and soil aggregate stability can depend on disturbance. Plant Soil 355:87-102. https:// doi.org/10.1007/s11104-011-1083-5 
R Core Team (2018) R: a language and environment for statistical computing. R Foundation for Statistical Computing, Vienna

Ravenek JM, Bessler H, Engels C, Scherer-Lorenzen M, Gessler A, Gockele A, de Luca E, Temperton VM, Ebeling A, Roscher C, Schmid B, Weisser WW, Wirth C, de Kroon H, Weigelt A, Mommer L (2014) Long-term study of root biomass in a biodiversity experiment reveals shifts in diversity effects over time. Oikos 123:1528-1536. https://doi.org/10.1111/oik.01502

Régent Instruments Inc (2013) WinRHIZO 2013 Reg, user manual. Régent Instruments Inc, Quebec City

Reubens B, Poesen J, Danjon F, Geudens G, Muys B (2007) The role of fine and coarse roots in shallow slope stability and soil erosion control with a focus on root system architecture: a review. Trees 21:385-402

Rillig MC, Mummey DL (2006) Mycorrhizas and soil structure. New Phytol 171:41-53. https://doi.org/10.1111/j. 1469-8137.2006.01750.x

Sauer D (2015) Pedological concepts to be considered in soil chronosequence studies. Soil Res 53:577-591. https://doi. org/10.1071/SR14282

Schimmelpfennig I, Schaefer JM, Akçar N, Koffman T, Ivy-Ochs S, Schwartz R, Finkel RC, Zimmerman S, Schlüchter C (2014) A chronology of Holocene and Little Ice Age glacier culminations of the Steingletscher, Central Alps, Switzerland, based on high-sensitivity beryllium-10 moraine dating. Earth Planet Sci Lett 393:220-230. https://doi.org/10.1016/j.epsl.2014.02.046

Stokes A, Atger C, Bengough AG, Fourcaud T, Sidle RC (2009) Desirable plant root traits for protecting natural and engineered slopes against landslides. Plant Soil 324:1-30. https://doi.org/10.1007/s11104-009-0159-y

Stokes A, Douglas GB, Fourcaud T, Giadrossich F, Gillies C, Hubble T, Kim JH, Loades KW, Mao Z, McIvor IR, Mickovski SB, Mitchell S, Osman N, Phillips C, Poesen J, Polster D, Preti F, Raymond P, Rey F, Schwarz M, Walker LR
(2014) Ecological mitigation of hillslope instability: ten key issues facing researchers and practitioners. Plant Soil 377:1-23. https://doi.org/10.1007/s11104-014-2044-6

Tilman D, Isbell F, Cowles JM (2014) Biodiversity and Ecosystem Functioning. Annu Rev Ecol Syst 45:471-493. https://doi.org/10.1146/annurev-ecolsys-120213-091917

Tisdall JM, Oades JM (1982) Organic matter and water-stable aggregates in soils. Eur J Soil Sci 33:141-163. https://doi. org/10.1111/j.1365-2389.1982.tb01755.x

Vannoppen W, Vanmaercke M, de Baets S, Poesen J (2015) A review of the mechanical effects of plant roots on concentrated flow erosion rates. Earth Sci Rev 150:666-678. https://doi.org/10.1016/j.earscirev.2015.08.011

Vítovcová K, Tichý L, Řehounková K, Prach K (2021) Which landscape and abiotic site factors influence vegetation succession across seres at a country scale? J Veg Sci 32:e12950. https://doi.org/10.1111/jvs. 12950

Walker LR, del Moral R (2003) Primary succession and ecosystem rehabilitation. Cambridge University Press, Cambridge

Yang S, Jansen B, Absalah S, van Hall RL, Kalbitz K, Cammeraat ELH (2020) Lithology- and climate-controlled soil aggregate-size distribution and organic carbon stability in the Peruvian Andes. Soil 6:1-15. https://doi.org/10.5194/ soil-6-1-2020

Zuur AF, Ieno EN, Elphick CS (2010) A protocol for data exploration to avoid common statistical problems. Methods Ecol Evol 1:3-14. https://doi.org/10.1111/j.2041210X.2009.00001.x

Publisher's note Springer Nature remains neutral with regard to jurisdictional claims in published maps and institutional affiliations. 